Article

\title{
On-Off Control Strategy in a BWRO System under Variable Power and Feedwater Concentration Conditions
}

\author{
A. Ruiz-García * and I. Nuez \\ Department of Electronic and Automatic Engineering, University of Las Palmas de Gran Canaria, \\ 35017 Las Palmas de Gran Canaria, Gran Canaria, Spain; ignacio.nuez@ulpgc.es \\ * Correspondence: alejandro.ruiz@ulpgc.es; Tel.: +34-928-451-888
}

Received: 23 June 2020; Accepted: 3 July 2020; Published: 10 July 2020

check for updates

\begin{abstract}
Although reverse osmosis (RO) is the technology of choice for solving water shortage problems, it is a process that consumes large amounts of energy. Brackish water (BW) desalination is more efficient than seawater desalination due to the lower salinity of the feedwater source. This makes coupling renewable energy sources with BWRO systems attractive. The operation of this type of systems is complex and requires the design of control strategies to obtain optimal operation. The novelty of this work was to propose a simple on-off control strategy for operating a BWRO system that can work with one and two stages and with different configurations considering six spiral wound membrane elements per pressure vessel (PV). The feedwater quality variations of a real groundwater well were used together with a computational tool to simulate the response of the different configurations with the purpose of selecting the most appropriate depending on the input power to the BWRO system. The most suitable configurations were found to be 1:0, 2:1 and 3:2 (PV first stage:PV second stage). It was additionally found that increased feedwater concentrations resulted in shorter operating ranges to maximize permeate water production for the 1:0 and 2:1 configurations, and that the 3:2 configuration was the most suitable for most of the operating range.
\end{abstract}

Keywords: desalination; reverse osmosis; process control; optimization; variable regime

\section{Introduction}

Reverse osmosis (RO) is the predominant technology in seawater and brackish water desalination [1]. However, this technology continues to be an intensive energy consumption process [2,3]. Various options can be pursued with the aim of reducing the specific energy consumption $(S E C)$ of $\mathrm{RO}$ [4-6], including optimizing the operation of $\mathrm{RO}$ desalination plants. Advances in RO membrane technology $[7,8]$ are a key element in the goal of improving desalination efficiency. With respect to spiral-wound membrane modules (SWMMs), studies have been made on the effect of the permeability coefficients on the performance of RO systems in terms of production and solute rejection [9-11]. Significant efforts are being made to try to inhibit the effect of fouling on permeability coefficients during operating time by improving pre-treatment processes [12] and the resistance to fouling [13]. The application of renewable energy sources (RES) to power RO systems has attracted much interest [14]. The operation of RES-driven RO systems is considerably complicated by the problem of variations in power availability and in the characteristics of the feedwater. Given the operational complexity of RO systems and the importance of taking full advantage of technological improvements, it is essential to ensure that desalination plants are working at all times under appropriate operating conditions through efficient and effective process control [15,16].

Models that estimate the behavior of RO systems are crucial when control strategies are applied to this kind of process. I.M. Alatiqi et al. [17] proposed the first multi-loop control system for a seawater 
RO (SWRO) process. The RO system had 4-inch hollow-fiber membranes (HFM) (B-10 Permasep from Dupont $\left.{ }^{\circledR}\right)$, which are not very common nowadays. Plant modeling was carried out using transfer functions, considering feed pressure $\left(p_{\mathrm{f}}\right)$ and $\mathrm{pH}_{\mathrm{f}}$ as inputs and permeate flow $\left(Q_{\mathrm{p}}\right)$ and permeate conductivity $\left(\mathrm{Cond}_{\mathrm{p}}\right)$ as outputs. M.W. Robertson et al. [18] presented an algorithm based on dynamic matrix control (DMC) for the control of an SWRO pilot plant. The process modeling of I.M. Alatiqi et al. [17] was used in this work. J.Z. Assef et al. [19] carried out a study on constrained model predictive control (CMPC) for a brackish water RO (BWRO) desalination unit. The process modeling was done considering four outputs $\left(Q_{\mathrm{p}}, \operatorname{Cond}_{\mathrm{p}}\right.$, trans-membrane pressure and $\left.\mathrm{pH}_{\mathrm{f}}\right)$ and two inputs (rejection flow $\left(Q_{\mathrm{b}}\right)$ and inlet acid flow). The goal was to produce a specified $Q_{p}$ with a desired $\mathrm{Cond}_{\mathrm{p}}$, subject to the constraint that $\mathrm{pH}_{\mathrm{f}}$ and trans-membrane pressure were within specified bounds. A. Abbas [20] used a DMC algorithm with and without constraints for the control of a simulated SWRO desalination unit with HFM. The dynamic model used in their work was based on transfer functions and developed in a previous study by other authors [17]. A control system design for RO systems using advanced optimization techniques was proposed by A. Gambier et al. [21]. Trans-membrane pressure and $\mathrm{pH}_{\mathrm{f}}$ were considered as inputs, and $Q_{\mathrm{p}}$ and $\mathrm{Cond}_{\mathrm{p}}$ as outputs in the transfer function-based model. A.R. Bartman et al. [22] designed and implemented a nonlinear model-based control system for a pilot-scale BWRO desalination plant. The model [23] used was based on a mass balance taken around the entire system and on an energy balance taken around the actuated concentrate valve. The model proposed by M.W. Robertson et al. [18] was implemented by G. Kim et al. [24] in an optimization algorithm with an immune-genetic approach to obtain the parameters of a proportional-integral-derivative (PID) controller. The previously mentioned mass/energy-based model proposed by C.W. McFall et al. [23] was used by A.R. Bartman et al. [25] in a simulated BWRO system with concentrate recirculation. In a later work, A.R. Bartman [26] minimized the SEC of an SWRO system (18 pressure vessels (PVs) each with 6 SWMMs in series) through a non-linear optimization model. A robust model-based control for an RO desalination unit with tubular membranes was proposed by M. Al-haj Ali et al. [27]. The three-parameter nonlinear Spiegler-Kedem model was used in this work. The same model was used by A. Emad et al. [28] in a periodic control work in a tubular RO process. A. Gambier [29] designed a robust PID controller using a multi-objective normal boundary intersection algorithm. A pilot BWRO desalination plant for tap water purification was used. The model of the aforementioned plant was simplified to a single-input single-output (SISO) system, where input was the RO concentrate valve position and output the permeate flow. M.M. AlDhaifallah et al. [30] designed a PID controller for a simulated SWRO system with HFMs using the solution-diffusion model. D. Li et al. [31] proposed a cascade control system for a simulated RO system with SWMMs. The models (steady state and dynamic) used had previously been proposed by T. Zhao et al. [32], and were based on solution-diffusion, mass balance and momentum balance. S. Sobana and R.C. Panda [33] studied model-based controls in a simulated SWRO system taking into consideration servo and regulatory problems. The model was based on transfer functions and the outputs were $Q_{\mathrm{p}}$, permeate concentrate $\left(C_{\mathrm{p}}\right)$ and $\mathrm{pH}_{\mathrm{f}}$ and the inputs $p_{\mathrm{f}}$ and flux recovery $R$. A modified PID control with H-infinity loop shaping synthesis for simulated RO systems was proposed by B.D.H. Phuc et al. [34]. A transfer function model was obtained for the RO system considering angular pump speed and $\mathrm{RO}$ concentrate valve position as inputs and $Q_{\mathrm{p}}$ and $C_{\mathrm{p}}$ as outputs. In a later work [35], the same authors carried out a dynamical analysis and control synthesis for RO systems against water hammering. In this case, a dynamical model based on a macroscopic kinetic energy balance and irreversible thermodynamics previously developed by A.R. Bartman et al. [25] was used. V. Feliu-Batlle et al. [36] used a transfer function-based model to propose a fractional order controller for a SWRO system. The dynamics of the system were experimentally identified. A control system comprised of two loops, the first using a loop-shaping design method and the second a super-twisting sliding mode control, was proposed by M. Zebbar et al. [37]. The RO system model was based on mass and energy balances. An implementation of an expert model predictive controller in a pilot BWRO and SWRO system was carried out by R. Rivas-Perez et al. [16]. The expert controller included an 
identification block with on-line calculation of the parameters of the prediction model. The model for the RO systems was based on transfer functions. W. Khiari et al. [38] proposed a power control strategy for a BWRO desalination plant powered by an isolated hybrid photovoltaic/wind source without battery. A solution-diffusion model was used for the RO process. Experimental work was done to determine performances under different operating conditions in the safe operating window (SOW). Different feedwater concentrations were considered $\left(2,4\right.$ and $\left.6 \mathrm{~g} \mathrm{~L}^{-1}\right)$ and $R$ was limited to $20 \%$. The proposed control system allowed operation of the BWRO desalination plant for a wide range of power variations. Most of the aforementioned works used process modeling based on transfer functions or more precise models without experimental validation.

Under normal conditions, BWRO is more efficient than SWRO desalination due to the difference in the osmotic pressure of the feedwater solutions. This makes the use of RES an attractive option to power BWRO desalination systems. The composition of groundwater, one of the main feedwater sources tends to fluctuate as the result of variations in different factors (temperature, rainfall, agricultural irrigation, etc.) $[39,40]$. Significant fluctuations in osmotic pressure may occur that can affect the performance of BWRO systems. Several authors have studied RES-powered BWRO systems. S.M. Hasnain and S.A. Alajlan [41] studied a BWRO system powered by photovoltaic energy using real groundwater. A pilot plant was used and the study focused on cost assessment without providing operating data. W. Gocht et al. [42] used a pilot BWRO desalination plant with a $Q_{\mathrm{p}}$ capacity of $40 \mathrm{~m}^{3} \mathrm{~d}^{-1}$. A. Schäfer et al. [43] carried out a performance analysis of a photovoltaic-powered hybrid BWRO membrane system considering variations in feedwater salinity. The RO system only had one membrane element and SEC variations of between $5.5 \mathrm{kWh} \mathrm{m}^{-3}$ at a feed concentration of $1 \mathrm{~g} \mathrm{~L}^{-1}$ salt and $26 \mathrm{kWh} \mathrm{m}^{-3}$ at a feed concentration of $7.5 \mathrm{~g} \mathrm{~L}^{-1}$ salt were reported. The same research group $[44,45]$ continued their study by evaluating the effect of energy fluctuations and feed salinity on the performance of a small single-stage BWRO system. The SEC and permeate quality were evaluated for different membranes along $12 \mathrm{~h}$ of operation. M. Khayet et al. [46] carried out an interesting work based on the optimization of a solar-powered BWRO system with a $Q_{\mathrm{p}}$ capacity of $0.2 \mathrm{~m}^{3} \mathrm{~d}^{-1}$ for drinking water. A synthetic solution of $6 \mathrm{~g} \mathrm{~L}^{-1} \mathrm{NaCl}$ was used as feedwater in the aforementioned small single-stage plant. Runs of $2 \mathrm{~h}$ were done providing operating data in terms of production, salt rejection and energy. The authors concluded that the optimized RO plant could guarantee potable water production with a $S E C$ from 1.2 to $1.3 \mathrm{kWh} \mathrm{m}^{-3}$. H. Quiblawey et al. [47] analyzed the performance of a small, single-stage photovoltaic-powered BWRO desalination plant to produce $0.5 \mathrm{~m}^{3} \mathrm{~d}^{-1}$. The variation of $R$ and salt rejection with temperature and the increase of $S E C$ when $R$ decreased were reported. H. Cherif and J. Belhadj [48] evaluated a hybrid photovoltaic-wind system to produce desalinated water from a BW source. The BWRO desalination plant design was based on software simulation (ROSA software from Dupont ${ }^{\circledR}$ ). The first stage had 4 PVs, each with 4 SWMMs, and the second stage 4 PVs, each with 2 SWMMs. G.L. Park et al. [49] studyied the effect of wind speed fluctuation on the performance of an RES-powered BWRO plant comprised of one 4-inch diameter SWMM element. They used synthetic solutions of $\mathrm{NaCl}\left(2.75\right.$ and $\left.5.5 \mathrm{~g} \mathrm{~L}^{-1}\right)$ as feedwater in a system with a $Q_{\mathrm{f}}$ capacity of $0.3 \mathrm{~m}^{3} \mathrm{~h}^{-1}$. Similarly, B.S. Richards et al. [50] considered the effect of real wind fluctuation and energy buffering on the performance of a BWRO pilot plant in terms of $Q_{\mathrm{p}}, C_{\mathrm{p}}$ and $S E C$. The same group continued this research line considering a small single-stage BWRO system unit, studying a safe operating window methodology using a new and old SWMM [51] and the influence of solar irradiance fluctuation on plant performance [52]. Most of the studies that have been undertaken have only considered small size (pilot-scale or lab-scale) single-stage BWRO system configurations which differ considerably from full-scale BWRO systems that commonly have at least two stages and 4 SWMMs per PV [5,53].

The aim of this work was to evaluate through an on-off control strategy the different SOWs of a simulated BWRO system using the real feedwater fluctuation characteristics of a groundwater well that has been under study for 10 years. The BWRO system has three PVs in the first stage and 2 PVs in the second stage. Depending on the power input and $C_{\mathrm{f}}$ in the BWRO system, the control 
system established a BWRO system configuration to maximize $Q_{\mathrm{p}}$. A computational tool validated in a previous work by the authors [53] was used to simulate the behavior of the BWRO systems under different operating conditions.

\section{Methodology}

\subsection{Feedwater Characterization}

The feedwater source (groundwater well) is located on the island of Gran Canaria (Canary Islands, Spain), with coordinates latitude $27^{\circ} 50^{\prime} 52.04^{\prime \prime} \mathrm{N}$, longitude $15^{\circ} 29^{\prime} 00.20^{\prime \prime} \mathrm{W}$, and an elevation of $160 \mathrm{~m}$ above mean sea level. The feedwater characteristics as well as how the samples were collected and analyzed have been published by the authors in a previous work [54]. The well was monitored for 10 years, taking two or three samples per year. Table 1 shows the feedwater characteristics in terms of $\mathrm{pH}, \mathrm{T}$ and inorganic composition. The total dissolved salts (TDS) content was considered as the sum of the analyzed ions and not the measurement of TDS itself as not every single ion was analyzed. The highest TDS were found in sample $11\left(5815.20 \mathrm{mg} \mathrm{L}^{-1}\right)$ and the lowest in sample $20\left(1218.79 \mathrm{mg} \mathrm{L}^{-1}\right)$. The silt density index (SDI) was assumed to be between 2 and 3, as is usual for this type of water after a $5 \mu \mathrm{m}$ microfiltration stage [55].

Table 1. Feed water inorganic composition in $\mathrm{mg} \mathrm{L}^{-1}$.

\begin{tabular}{llllllllllllll}
\hline Sample & $\mathbf{p H}$ & $\mathbf{H C O}_{3}{ }^{-}$ & $\mathbf{C l}^{-}$ & $\mathbf{S O}_{4}{ }^{2-}$ & $\mathbf{N O}_{3}{ }^{-}$ & $\mathbf{N a}^{+}$ & $\mathbf{K}^{+}$ & $\mathbf{C a}^{2+}$ & $\mathbf{M g}^{2+}$ & $\mathbf{F e}^{2+}$ & $\mathbf{S i O}_{2}$ & $\mathbf{T D S}$ & $\mathbf{T}$ \\
\hline 1 & 7.05 & 175 & 2620 & 165 & 7.9 & 400 & 29 & 474 & 475 & 0.6 & 60.5 & 4407.00 & 25.20 \\
2 & 6.94 & 155 & 2500 & 180 & 5.3 & 422 & 38 & 532 & 383 & 0.2 & 36 & 4251.50 & 25.60 \\
3 & 7.37 & 175 & 2650 & 168 & 5.3 & 450 & 30 & 561 & 406 & 0.15 & 55.7 & 4501.15 & 25.00 \\
4 & 7.48 & 100 & 2420 & 192 & 5.7 & 307 & 30 & 512 & 409 & 0.11 & 53.4 & 4029.21 & 25.10 \\
5 & 7.24 & 122 & 1715 & 150 & 6.9 & 257 & 28 & 368 & 292 & 0.09 & 52.5 & 2991.49 & 24.90 \\
6 & 7.27 & 216 & 2230 & 323 & 9.6 & 369 & 30 & 480 & 399 & 0.1 & 65 & 4121.70 & 25.50 \\
7 & 7.05 & 190 & 3180 & 306 & 3 & 458 & 17 & 783 & 483 & 0.35 & 57 & 5477.35 & 25.30 \\
8 & 7.05 & 167 & 2418 & 175 & 6 & 451 & 29 & 660 & 264 & 0.5 & 57 & 4227.50 & 25.00 \\
9 & 7.03 & 92 & 2680 & 166 & 4.3 & 339 & 35 & 605 & 428 & 0.13 & 30 & 4379.43 & 24.80 \\
10 & 7.46 & 287 & 2684 & 196 & 1 & 720 & 48 & 432 & 370 & 0.09 & 59 & 4797.09 & 25.40 \\
11 & 7.10 & 304 & 3362 & 180 & 2.2 & 830 & 85 & 566 & 453 & 1 & 32 & 5815.20 & 25.70 \\
12 & 7.10 & 305 & 3360 & 180 & 2 & 828 & 83 & 570 & 450 & 0.8 & 30 & 5808.80 & 25.00 \\
13 & 7.40 & 184 & 2420 & 182 & 1.4 & 324 & 32 & 570 & 390 & 0.27 & 56.3 & 4159.97 & 25.20 \\
14 & 7.10 & 185 & 2872 & 200 & 5 & 383 & 28.9 & 594 & 505 & 0.48 & 55.8 & 4829.18 & 25.10 \\
15 & 7.80 & 155 & 2610 & 209 & 0.5 & 399 & 38.1 & 645 & 405 & 0.21 & 92.9 & 4554.71 & 25.00 \\
16 & 7.40 & 152 & 2966 & 273 & 12.9 & 469 & 33.6 & 600 & 504 & 0.19 & 54.5 & 5065.19 & 24.80 \\
17 & 6.90 & 260 & 3023 & 218 & 5 & 425 & 36.9 & 632 & 552 & 0.08 & 54.7 & 5206.68 & 24.60 \\
18 & 7.70 & 173 & 2930 & 253 & 6.8 & 410 & 17 & 620 & 504 & 0.14 & 46 & 4959.94 & 25.70 \\
19 & 7.00 & 170 & 2758 & 232 & 7.2 & 363 & 38.2 & 669 & 546 & 0.15 & 50.8 & 4834.35 & 25.50 \\
20 & 7.60 & 215 & 484 & 85.6 & 13.6 & 208 & 11.7 & 76.8 & 78.1 & 0.094 & 45.9 & 1218.79 & 25.00 \\
21 & 8.04 & 193 & 1831 & 150 & 8.36 & 468 & 22.5 & 395 & 323 & 0.17 & 52.1 & 3443.13 & 25.50 \\
22 & 8.19 & 197 & 1715 & 148 & 8.1 & 622 & 28.6 & 423 & 308 & 0.11 & 34.2 & 3484.01 & 25.20 \\
23 & 7.72 & 227 & 654 & 108 & 6.73 & 214 & 15.6 & 120 & 88.5 & 1.21 & 66.6 & 1501.64 & 25.10 \\
24 & 7.58 & 196 & 2259 & 152 & 74.8 & 354 & 35.1 & 465 & 418 & 1.22 & 62.3 & 4017.42 & 25.00 \\
\hline & & & & & & & & & & & & &
\end{tabular}

\subsection{Bwro Desalination System}

The BWRO system considered for this study has 3 PVs in the first stage and 2 PVs in the second stage (3:2) and is shown in Figure 1. Six SWMMs per PV were considered along with a FILMTEC ${ }^{\mathrm{TM}}$ membrane module. The BW30-400 computational tool used was validated with experimental data of full-scale BWRO desalination plants with the aforementioned SWMMs installed [53]. In the cited study, the purpose of the computational tool had been to provide optimal BWRO designs. In the present study, this tool is used to simulate the operating windows of the different configurations under different $C_{\mathrm{f}}$. PVs of 6 SWMMs were considered as this is a typical PV size [53]. Valves 1 to 6 allowed the configuration of the BWRO system to be changed depending on the feedwater solute concentration 
and the input power $\left(P_{\text {in }}\right)$ to the system. Non-return valves have to be installed (not shown in Figure 1) to avoid reverse flow to PVs that are in off position. The $P_{\mathrm{in}}$, supplied by the high pressure pump (output power of the high pressure pump) is a manipulable variable that depends on $Q_{\mathrm{f}}$ and $p_{\mathrm{f}}$ set by the variable frequency drive of the high pressure pump. Another manipulable variable is $R$ through the reject flow which depends on the on/off percentage of the RO concentrate valve. Specific high pressure pumps and their performances were not considered in this study. The different configurations that could be established were 1:0, 2:0, 3:0, 2:1, 3:1 and 3:2. For each $P_{\text {in }}$ and system configuration, the operating point that provided maximum production was selected as the use of RES to power the BWRO system was assumed. Most BWRO desalination plants in Gran Canaria are used for agricultural irrigation purposes so no permeate quality restrictions were added.

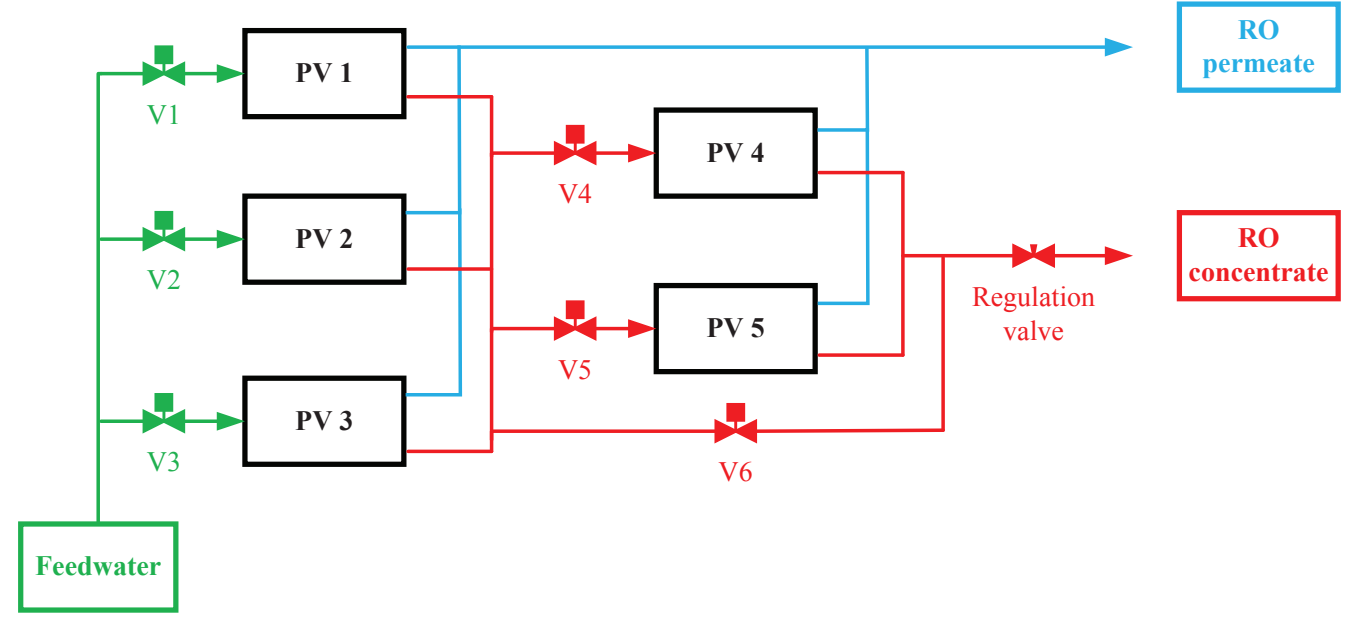

Figure 1. Brackish water reverse osmosis (BWRO) desalination system.

\subsection{Process Modeling}

The solution-diffusion transport model [56,57], which presumes that the RO membrane does not have porous or imperfections, was utilized. This model is based on considering that each solvent and solute are dissolved in the membrane separately on the feed-brine side and then diffused in individual fluxes through the membrane under the effect of pressure and concentration gradients. This is the most extended model and provides results close to the real behavior of RO systems for both seawater and brackish water [58]. The mentioned transport model was implemented in the algorithm [53] as it usually provides results close to the real behavior of these systems. The transport equations used mean membrane element values, and permeate pressure drops as well as $T$ changes along the $\mathrm{RO}$ system were disregarded. The calculation algorithm considers some simplifications that have been detailed in a previous work [53]. Figure 2 shows the inputs and outputs of the calculation algorithm considering the constraints established by the membrane manufacturer (maximum permeate flow $\left(Q_{\mathrm{p}-\mathrm{max}}\right)$, minimum rejection flow $\left(Q_{\mathrm{r}-\mathrm{min}}\right)$ and maximum feed flow $\left(Q_{\mathrm{f}-\mathrm{max}}\right)$. One of the main limiting factors in BWRO desalination is the presence of poorly soluble compounds in the feedwater that can cause scaling. As a result, antiscalant products are commonly used in BWRO desalination plants to avoid the problems caused by scaling and increase the maximum flux recovery $\left(R_{\max }\right) \cdot R_{\max }$ depends, amongst other things, on the type of antiscalant that is used. The calculation algorithm has a specific function ( $\mathrm{R}$ function) where $R_{\max }$ is calculated for various antiscalants [59]. The aforementioned algorithm provides the possible operating points in accordance with the considered constraints and BWRO system configurations. With the inputs, the algorithm calculates the outputs considering the mean operating parameter values per SWMM. The calculation algorithm assumes a negligible pressure decrease on the permeate side, constant pressure drop along the membrane elements on the feed-brine side, constant permeate flow per membrane element, constant feed-brine concentration $\left(C_{\mathrm{fb}_{\mathrm{i}}}\right)$ on the 
membrane surface $\left(C_{\mathrm{m}_{\mathrm{i}}}\right)$ and constant membrane element feed pressure $\left(p_{\mathrm{f}_{\mathrm{i}}}\right)$. Equations (1) and (2) [60] were used to determine the outputs of the BWRO system.

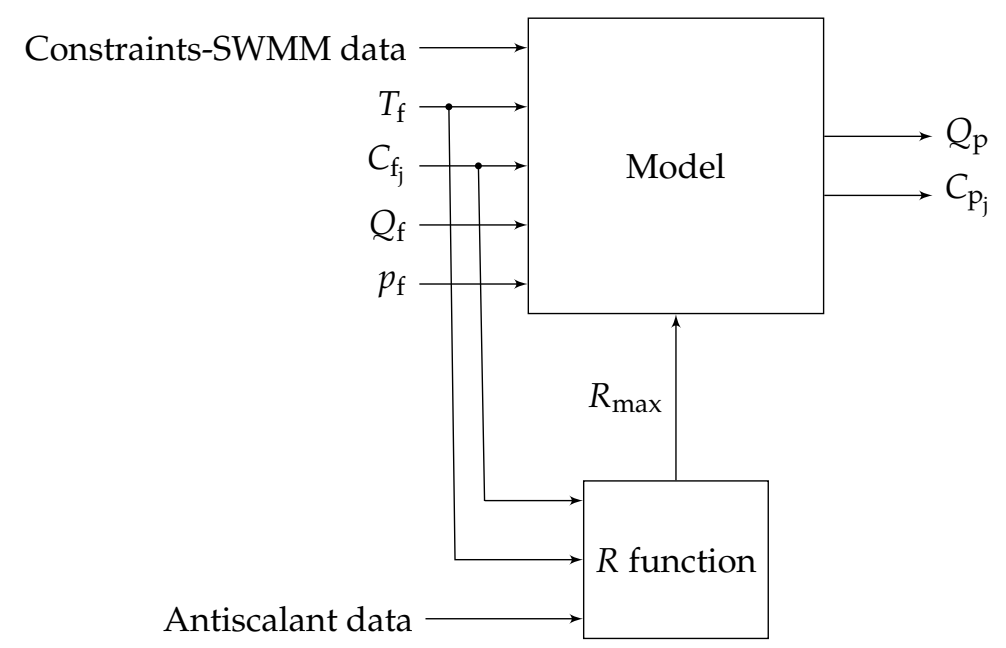

Figure 2. Inputs and outputs of the calculation algorithm.

$$
\begin{aligned}
& Q_{\mathrm{p}}=\sum_{i}^{n} Q_{\mathrm{p}_{i}}=\sum_{i}^{n}\left(A \cdot T C F \cdot F F \cdot S _ { \mathrm { m } _ { \mathrm { i } } } \cdot \left(p_{\mathrm{f}_{i}}-\frac{\mathrm{a} \cdot\left(\frac{Q_{\mathrm{f}_{i}}+Q_{\mathrm{r}_{i}}}{2}\right)^{\mathrm{b}} \cdot 0.07}{2}-p_{\mathrm{p}_{i}}-0.0787 \cdot(273+T) .\right.\right.
\end{aligned}
$$

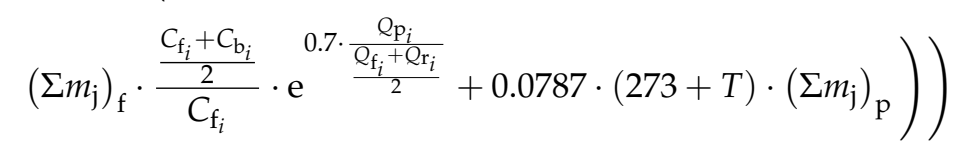

$$
\begin{aligned}
& C_{\mathrm{p}_{\mathrm{j}}}=B_{\mathrm{j}} \cdot \mathrm{e}^{0.7 \cdot\left(\frac{Q_{\mathrm{p}_{i}}}{\frac{Q_{\mathrm{f}_{i}}+Q_{\mathrm{r}_{i}}}{2}}\right)} \cdot T C F \cdot \frac{S_{\mathrm{m}}}{Q_{\mathrm{p}_{i}}} \cdot \frac{C_{\mathrm{f}_{\mathrm{j}}} \cdot\left(1+\frac{1}{1-\frac{Q_{\mathrm{p}}}{Q_{\mathrm{f}}}}\right)}{2}
\end{aligned}
$$

If $T \geqslant 25^{\circ} \mathrm{C}$ :

$$
T C F=\exp \left[2640 \cdot\left(\frac{1}{298}-\frac{1}{273+T}\right)\right]
$$

If $T \leqslant 25^{\circ} \mathrm{C}:$

$$
T C F=\exp \left[3020 \cdot\left(\frac{1}{298}-\frac{1}{273+T}\right)\right]
$$

where $Q_{\mathrm{p}}$ is the permeate flow of the RO system, $i$ is the membrane element $(1 \ldots n), n$ is the number of membrane elements in series, $Q_{p_{i}}$ is the permeate flow of the membrane element $i, A$ is the average water permeability coefficient of the membrane, TCF is the temperature correction factor, $F F$ is the fouling factor (considered $=1$, new SWMMs), $S_{\mathrm{m}_{\mathrm{p}}}$ is the membrane area, $a$ and $b$ are two parameters obtained experimentally to calculate the pressure drop, $p_{p_{i}}$ is the permeate pressure (considered as $5 \mathrm{psi}), T$ is the feed temperature, $m$ is the molal concentration of each ion $\mathrm{j}, C_{\mathrm{b}}$ is the concentration in the brine, $B$ is the average ion permeability coefficient of the membrane. The $p_{\mathrm{f}}$ range considered was between 7 and 20 bar in steps of 0.5 bar, and the $Q_{\mathrm{f}}$ range between $Q_{\mathrm{r}-\min }$ and $Q_{\mathrm{f} \text {-max }}$ in steps of $10 \mathrm{~m}^{3} \mathrm{~d}^{-1}$.

\section{Results and Discussion}

Figures 3 and 4 show the different SOWs considering the different BWRO configurations (1:0, 2:0...) and two different $C_{\mathrm{f}}\left(1.2\right.$ and $5.8 \mathrm{~g} \mathrm{~L}^{-1}$, respectively). The irregularities in the contours of the surfaces are due to the $p_{\mathrm{f}}$ and $Q_{\mathrm{f}}$ steps. It can be observed that with lower $C_{\mathrm{f}}$ there is greater separation along the $\mathrm{x}$-axis between the different SOWs. This is because low osmotic pressure of the 
feed solution allows water production with low $P_{\text {in }}$, which can result in SWMMs operating outside their recommended range (in terms of $Q_{r-m i n}$ ) due to the very high permeate production of the first SWMMs. Figure 3 shows a possible operating range for the 1.0 configuration at very low $P_{\text {in }}$. However, the 2:0, 3:0 and 3:1 configurations can be discarded, as higher permeate productions can be attained with the 2:1 and 3:2 configurations with the same $P_{\text {in }}$. The same occurs when considering higher $C_{\mathrm{f}}$ (Figure 4), although in this case the operating range of configuration 1:0 is shorter. Having higher $C_{\mathrm{f}}$ means higher osmotic pressure and a lower number of operating points that are outside the recommended range. This is because the first SWMMs do not produce a high amount of permeate due to osmotic pressure, resulting in the subsequent SWMMs remaining within the recommended range since, as we move along the PV, the SWMMs produce less permeate flow. For the solution with higher $C_{\mathrm{f}}$, operating conditions with higher $P_{\text {in }}$ were found to be suitable as higher osmotic pressure allows the BWRO system to remain within the SOW. However, the energy required is also higher and production is decreased compared to the case with lower $C_{\mathrm{f}}$. It can be appreciated how permeate production of more than $700 \mathrm{~m}^{3} \mathrm{~d}^{-1}$ can be obtained with sample 20 as feed solution (Figure 3), whereas, with sample 11 as feed solution, permeate production is below $600 \mathrm{~m}^{3} \mathrm{~d}^{-1}$ and more energy is required. The SOWs are affected by SWMM characteristics such as $S_{\mathrm{m}}$ or permeability coefficients. As a result of changes in these characteristics, there is a shift in the SOWS and, consequently, in the optimal operating points.

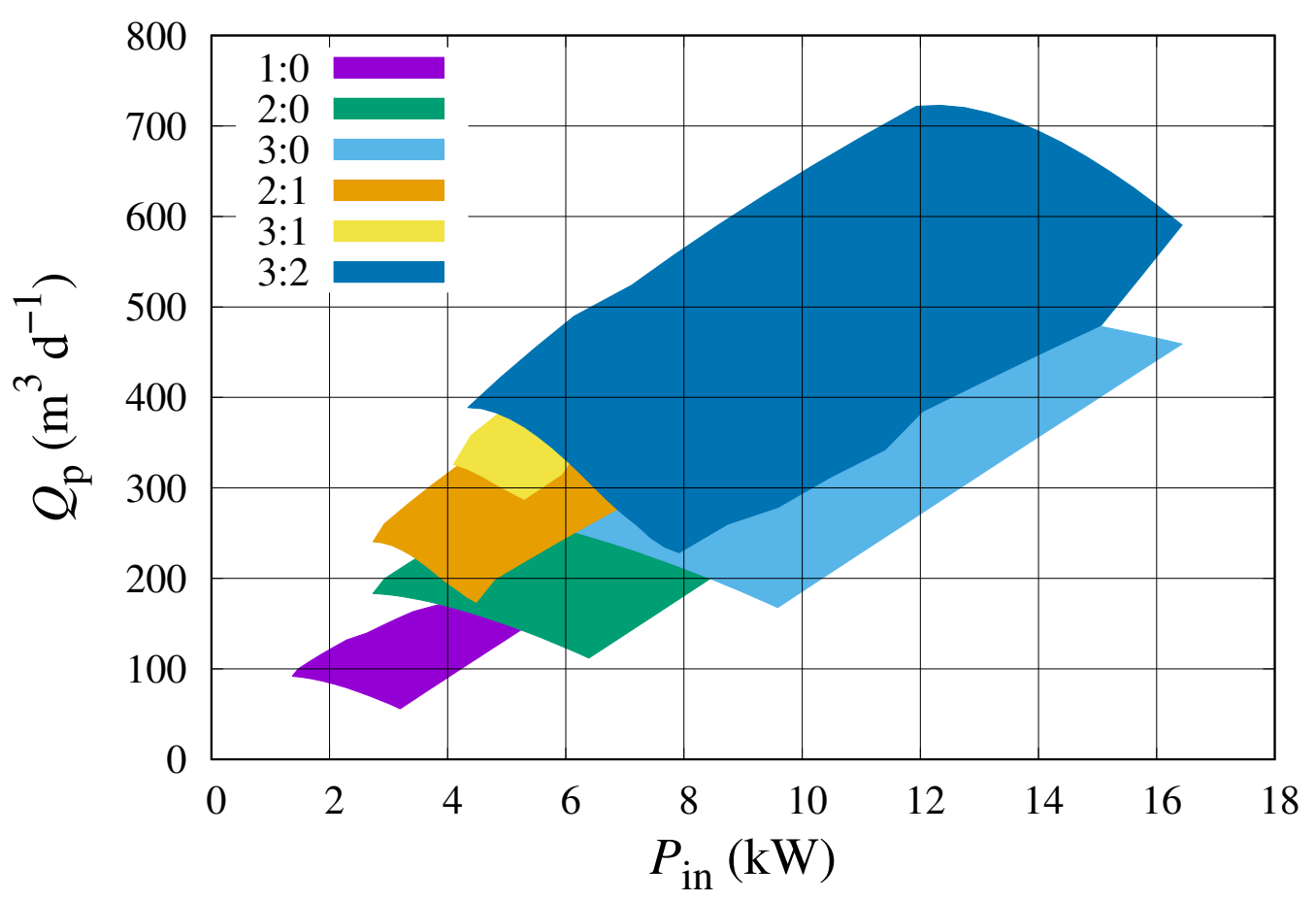

Figure 3. Permeate production for different BWRO configurations using sample 20 (Table 1) as $C_{\mathrm{f}}$. 


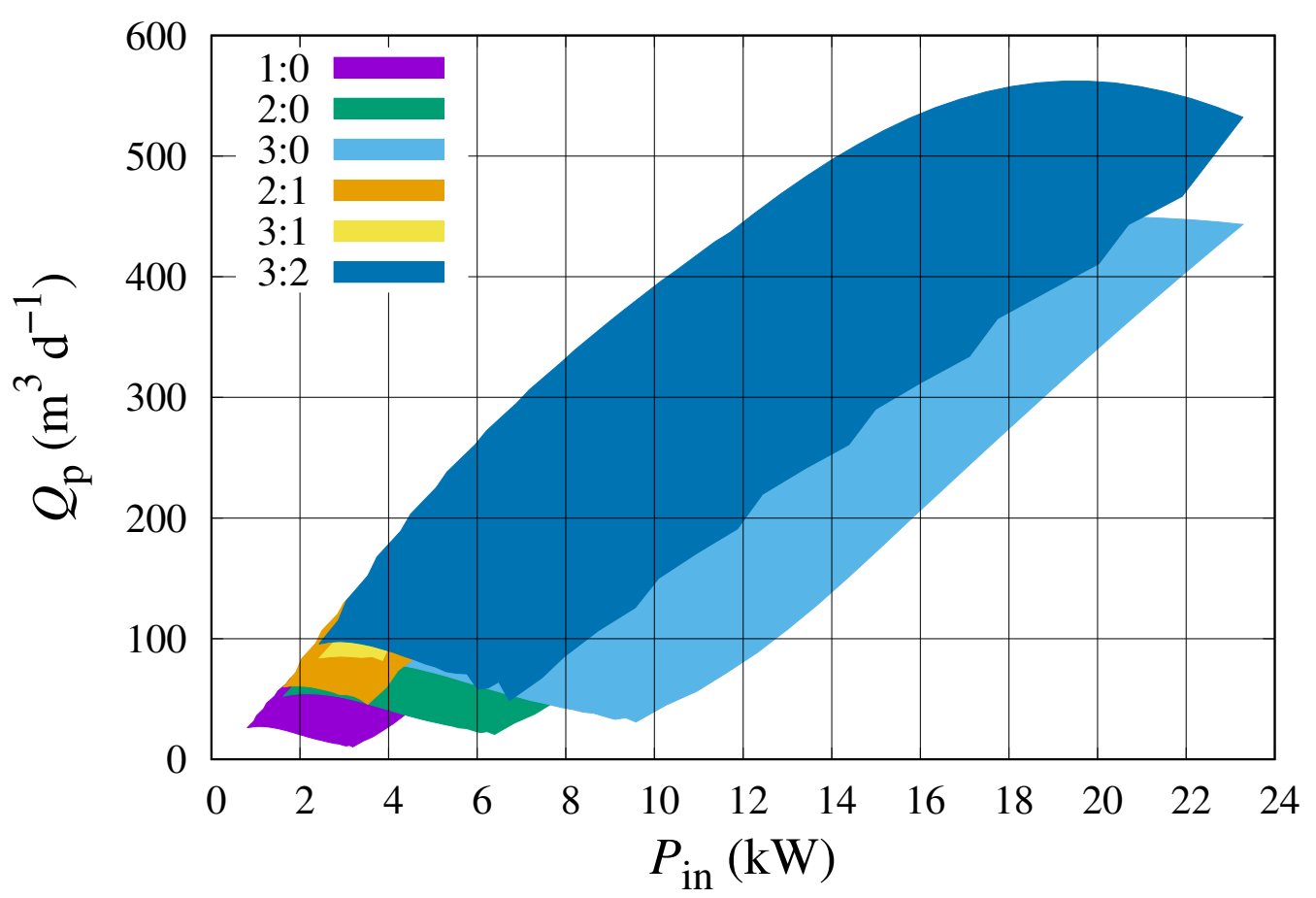

Figure 4. Permeate production for different BWRO configurations using sample 11 (Table 1) as $C_{\mathrm{f}}$.

Figures 5 and 6 show the $R$ for the most relevant BWRO system configurations (1:0, 2:1 and 3:2), considering the $C_{\mathrm{f}}$ of samples 20 and 11, respectively. A wider operating range can be observed for configuration 3:2. This is due to the higher number of SWMMs allowing more possible operating points without exceeding the membrane manufacturer constraints. Higher $R$ values were obtained for the configurations with two stages as more SWMMS are arranged in series in this sort of configuration. While the highest $R$ can be attained with both the 2:1 and 3:2 configurations, the 2:1 configuration requires less input power but has a lower production than the 3:2 configuration (Figure 3). The highest $R$ value attained with a single-stage configuration was around $60 \%$. Considering as $C_{\mathrm{f}}$ a feed solution with higher $T D S_{\mathrm{f}}\left(5.82 \mathrm{~g} \mathrm{~L}^{-1}\right)$, the surfaces of the three configurations considered are closer together, as observed previously (Figure 4 ). The change in feedwater inorganic composition results in a decrease in $R_{\max }$. With higher $T D S_{\mathrm{f}}$, the difference in terms of $R$ between the single- and two-stage configurations is lower. It should be mentioned that, in terms of production, the 2-stage configurations outperform the others as more SWMMs are arranged in series and so more elements are producing permeate. The influence of $T D S_{\mathrm{f}}$ (and therefore of $\pi$ ) can be observed by comparing Figures 5 and 6 . With the $3: 2$ configuration and a $P_{\text {in }}$ of $8 \mathrm{~kW}$, an $R$ of about $77 \%$ can be observed in Figure 5 compared to a value of about $64 \%$ in Figure 6. Naturally, this also affects the production of the system and its efficiency. 


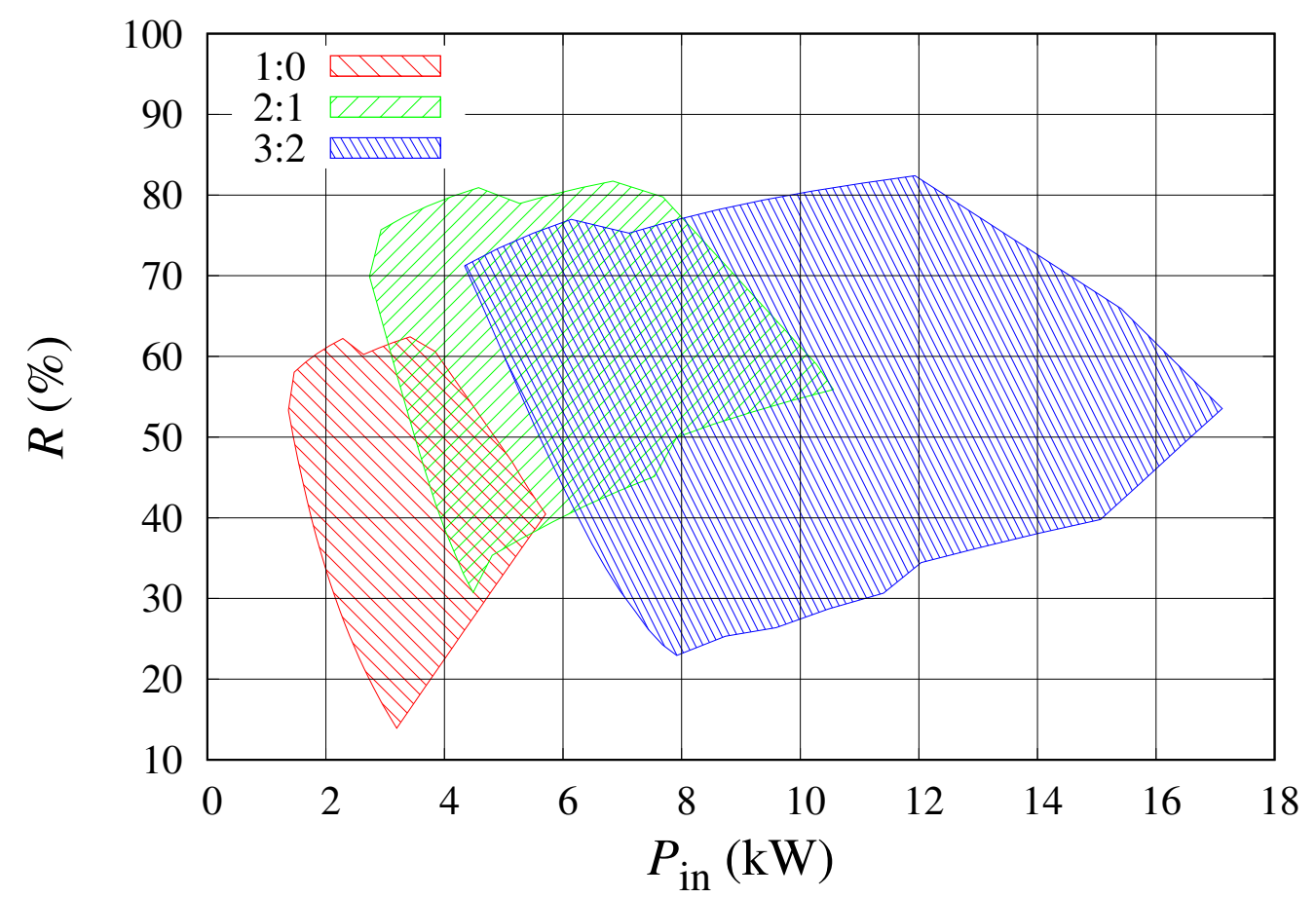

Figure 5. $R$ for different BWRO configurations using sample 20 (Table 1) as $C_{\mathrm{f}}$.

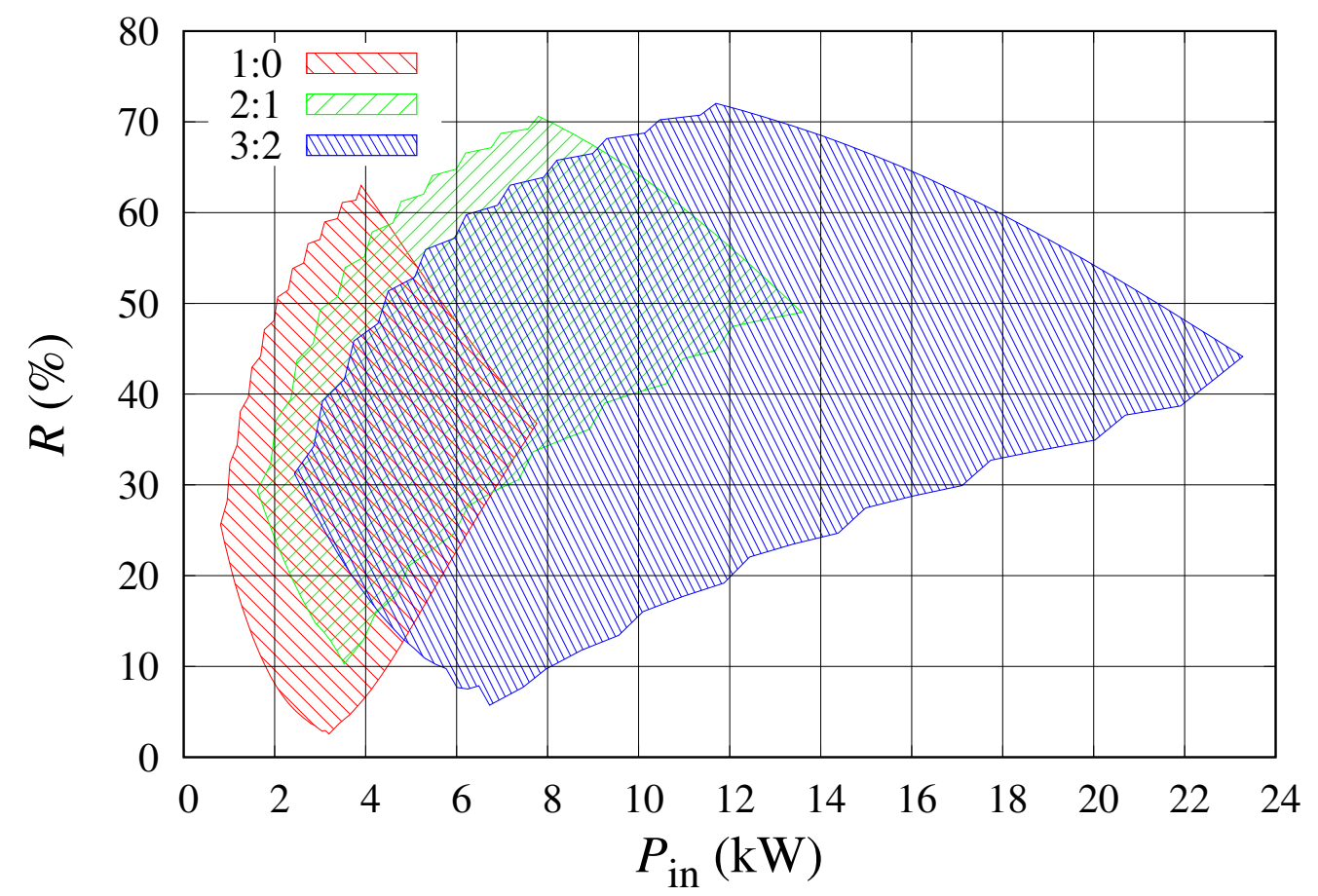

Figure 6. $R$ for different BWRO configurations using sample 11 (Table 1) as $C_{\mathrm{f}}$.

Figures 7 and 8 show the operating points that maximize $Q_{p}$ for the BWRO configurations 1:0, $2: 1$ and 3:2, considering the $C_{\mathrm{f}}$ of samples 20 and 11, respectively. It can be observed that with higher $C_{\mathrm{f}}$ the curves are closer together and even intersect. Another factor affected by $C_{\mathrm{f}}$ is the appropriate $P_{\text {in }}$ (for maximizing $Q_{p}$ ) range using each configuration. This range is notably lower for configurations 1:0 and 2:1. The operating curves of the 2:1 and 3:2 configurations are so close that a jump from 1:0 
to $3: 2$ can be made directly depending on the trend of $P_{\text {in }}$. It can be observed that the curves are longer for the feedwater with higher $C_{\mathrm{f}}$ than for sample 20 (lower $C_{\mathrm{f}}$ ). This is because at lower $C_{\mathrm{f}}$, SWMMs produce more $Q_{\mathrm{p}}$ and are more likely to not meet the $Q_{\mathrm{r}-\min }$ constraint or exceed the $Q_{\mathrm{p} \text {-max }}$ per SWMM. The BWRO system operation with higher $C_{\mathrm{f}}$ allows a wider operating range without exceeding the imposed constraints but producing a lower $Q_{\mathrm{p}}$ with the same $P_{\mathrm{in}}$.

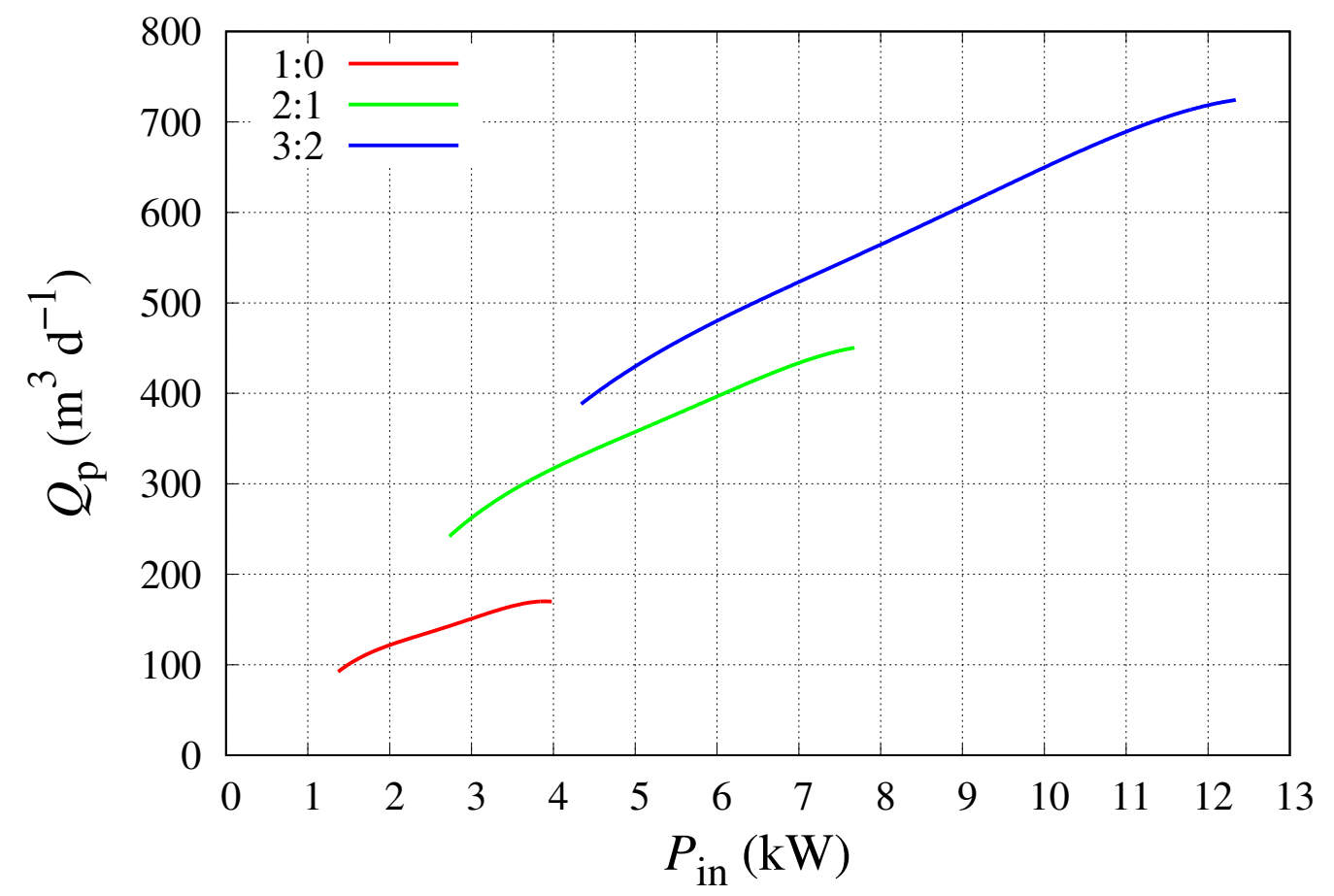

Figure 7. Curves of maximum $Q_{\mathrm{p}}$ for different $\mathrm{BWRO}$ configurations using sample 20 (Table 1) as $C_{\mathrm{f}}$.

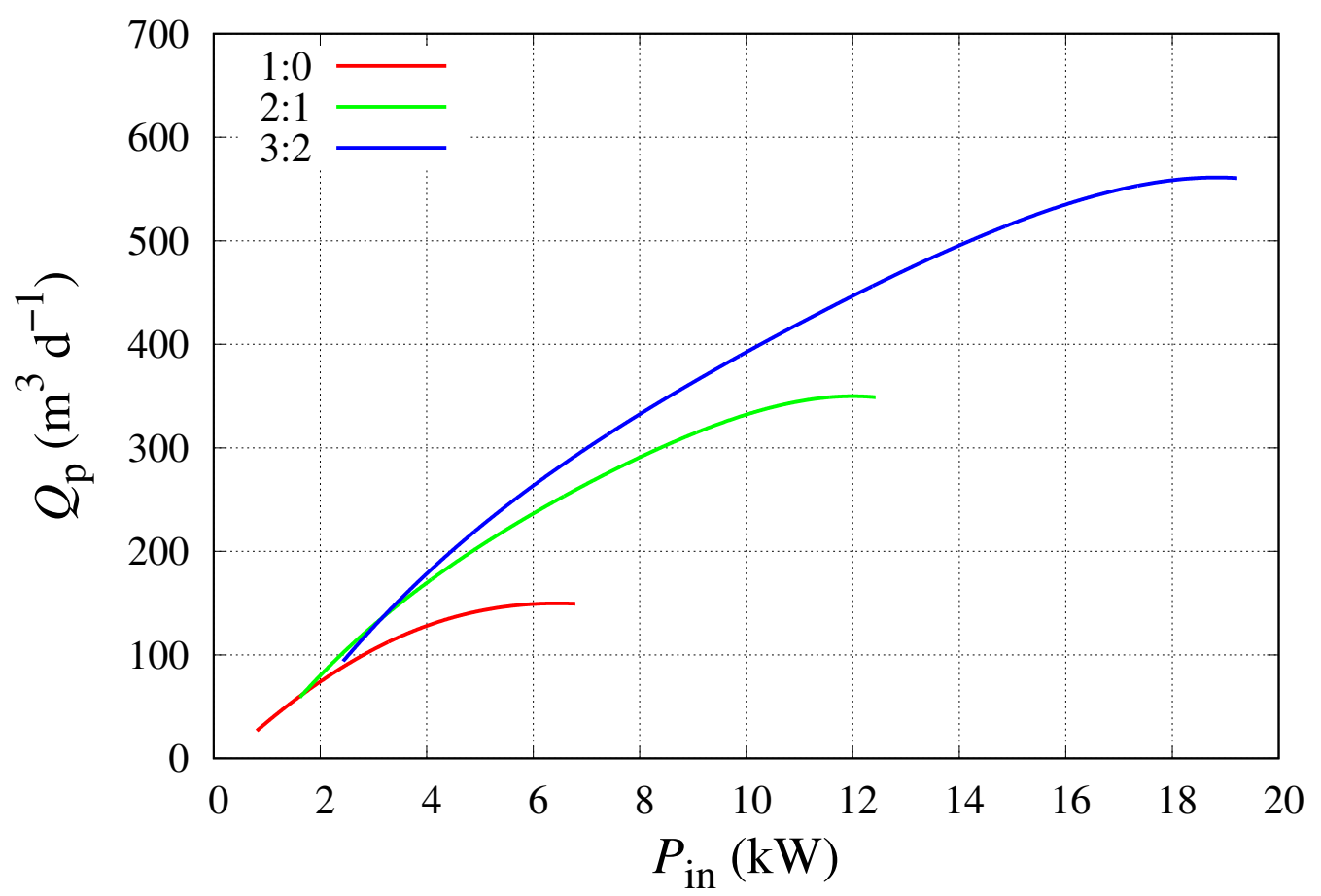

Figure 8. Curves of maximum $Q_{\mathrm{p}}$ for different $\mathrm{BWRO}$ configurations using sample 11 (Table 1) as $C_{\mathrm{f}}$. 
Table 2 shows the range of $P_{\text {in }}$ in which each BWRO configuration should be applied considering five samples $\left(20,5,22,3\right.$ and 11 (Table 1)) representing different $C_{\mathrm{f}}$ of the studied groundwater well. Some overlap was considered in $P_{\text {in }}$ to avoid excessive configuration changes, depending on the $P_{\text {in }}$ trend (increasing or decreasing). It should be mentioned that some operating points that were very close to the constraints established by the membrane manufacturer were removed to avoid instabilities in the operation of the BWRO system. This is the main reason why higher $P_{\text {in }}$ was required for lower $C_{\mathrm{f}}$ in addition to the selected $p_{\mathrm{f}}$ and $Q_{\mathrm{f}}$ steps that eliminate some possible operating points. The $P_{\text {in }}$ required depends, among other things, on the osmotic pressure of the feed solution, which in turn not only depends on the amount of TDS but on its inorganic composition. Table 3 shows the $R$ range for each configuration. These values are important as the reference for the on/off percentages of the RO concentrate valve (Figure 1). The data of the operating points for maximizing $Q_{\mathrm{p}}$ using configurations 1:0, 2:1 and 3:2 for the five samples shown in Tables 2 and 3 can be found in Appendix A.

Table 2. $P_{\text {in }}(\mathrm{kW})$ range for different BWRO configurations and five $C_{\mathrm{f}}$ (samples 20, 5, 22, 3 and 11 (Table 1)).

\begin{tabular}{lccccc}
\hline \multirow{2}{*}{ Configuration } & $\mathbf{1 . 2}$ & $\mathbf{2 . 9 9}$ & $\mathbf{C} \boldsymbol{C}_{\mathbf{f}}\left(\mathrm{g} \mathrm{L}^{-\mathbf{1}}\right)$ \\
\hline $1: 0$ & $1.37-2.89$ & $1.13-2.4$ & $1.13-2.4$ & $0.89-1.93$ & $0.81-2.07$ \\
$2: 1$ & $2.73-4.57$ & $2.26-3.71$ & $2.26-3.71$ & $1.78-2.90$ & $1.91-3.39$ \\
$3: 2$ & $4.34-12.34$ & $3.39-15.36$ & $3.39-17.26$ & $2.67-17$ & $3.05-19.22$ \\
\hline
\end{tabular}

Table 3. $R$ (\%) range for different BWRO configurations and five $C_{\mathrm{f}}$ (samples 20, 5, 22, 3 and 11 (Table 1)).

\begin{tabular}{lccccc}
\hline \multirow{2}{*}{ Configuration } & $\mathbf{1 . 2}$ & $\mathbf{2 . 9 9}$ & $\mathbf{3 . 4 8}$ & $\mathbf{4 . 5}$ & $\mathbf{5 . 8 2}$ \\
\hline $1: 0$ & $53.32-61.02$ & $43.13-59.88$ & $43.34-60.17$ & $35.66-50.60$ & $25.64-50.71$ \\
$2: 1$ & $69.92-80.91$ & $52.28-66.78$ & $52.45-66.96$ & $41.58-52.85$ & $32.27-50.76$ \\
$3: 2$ & $71.22-79.77$ & $55.68-66.82$ & $55.82-58.11$ & $43.99-61.13$ & $39.22-56.44$ \\
\hline
\end{tabular}

\section{Conclusions}

Operating a BWRO system is far from simple and acquires greater complexity under variable conditions of $C_{\mathrm{f}}$ (usual for groundwater sources) and $P_{\text {in }}$ (for example when the $\mathrm{BWRO}$ is powered by renewable energy sources). An on-off control strategy based on simulations is presented in this work considering a BWRO system with a 3:2 configuration that is able to operate with other configurations (1:0, 2:0, 3:0, 2:1 and 3:1) depending on the $P_{\text {in }}$ available. The operating points of each configuration that maximize $Q_{\mathrm{p}}$ for each $P_{\text {in }}$ were considered. The simulations showed that only the 1:0, 2:1 and 3:2 configurations were of interest in the studied case. Depending on the variation of $C_{\mathrm{f}}$ and the $Q_{\mathrm{f}}$ available from the source, larger BWRO systems are possible with a wider range of possible configurations. It was found that with higher $C_{\mathrm{f}}$ there was closer concordance between the SOWs for the different configurations considered. Lower $C_{\mathrm{f}}$ values allowed the BWRO system to produce more permeate water with a wider operating range for the 1:0, 2:1 and 3:2 configurations. In future works, high pressure pump performances and the modelling and control of variable frequency drives and $\mathrm{RO}$ concentrate valves should be considered to obtain more accurate results in the operation of this type of system under variable operating conditions. Permeate quality constraints were not considered in this study as the water product was assumed to be for agricultural irrigation. Consideration of a maximum $C_{p}$ would also be of interest in terms of its impact on SOWs and suitable operating ranges. 
Author Contributions: Formal analysis, A.R.-G.; investigation, A.R.-G.; writing-original draft preparation, A.R.-G.; writing-review and editing, A.R.-G. and I.N.; supervision, I.N. All authors have read and agreed to the published version of the manuscript.

Funding: This research was not funded.

Conflicts of Interest: The authors declare no conflict of interest.

\section{Abbreviations}

The following abbreviations are used in this manuscript:

Nomenclature

\begin{tabular}{|c|c|}
\hline$A$ & Average water permeability coefficient $\left(\mathrm{m} \mathrm{d}^{-1} \mathrm{bar}^{-1} \mathrm{~cm}^{2}\right)$ \\
\hline$B$ & Average ion permeability coefficient $\left(\mathrm{m} \mathrm{d}^{-1}\right)$ \\
\hline BWRO & Brackish water reverse osmosis \\
\hline C & Concentration $\left(\mathrm{mg} \mathrm{L}^{-1}\right)$ \\
\hline Cond & Conductivity $\left(\mathrm{vS} \mathrm{cm}^{-1}\right)$ \\
\hline$F F$ & Flow factor \\
\hline$n$ & Number of membrane elements in series \\
\hline$P_{\text {in }}$ & Input power $(\mathrm{kW})$ \\
\hline PID & Proportional-integral-derivative \\
\hline PV & Pressure vessel \\
\hline$p$ & Pressure (bar) \\
\hline$Q$ & Flow $\left(\mathrm{m}^{3} \mathrm{~d}^{-1}\right)$ \\
\hline$R$ & Flow recovery $(\%)$ \\
\hline $\mathrm{RO}$ & Reverse osmosis \\
\hline SEC & Specific energy consumption $\left(\mathrm{kW} \mathrm{h} \mathrm{m}^{-3}\right)$ \\
\hline SDI & Silt density index \\
\hline SOW & Safe operating window \\
\hline SWMM & Spiral wound membrane module \\
\hline$T$ & Temperature \\
\hline TCF & Temperature correction factor \\
\hline TDS & Total dissolved solids \\
\hline Y & Fraction recovery \\
\hline \multicolumn{2}{|c|}{ Greek letters } \\
\hline$\pi$ & Osmotic pressure (bar) \\
\hline \multicolumn{2}{|c|}{ Subscripts } \\
\hline $\mathrm{b}$ & Brine \\
\hline $\mathrm{f}$ & Feed \\
\hline$i$ & Membrane element $i$ \\
\hline j & Ion $\mathrm{j}$ \\
\hline $\max$ & Maximum \\
\hline $\min$ & Minimum \\
\hline $\mathrm{p}$ & Permeate \\
\hline $\mathrm{r}$ & Rejection \\
\hline
\end{tabular}


Appendix A. Operating Conditions for Maximizing $Q_{\mathrm{p}}$ Considering Three Bwro Configurations and Five Different Feedwater Samples

Table A1. $P_{\text {in }}, p_{\mathrm{f}}, Q_{\mathrm{f}}$ and $R$ for maximizing $Q_{\mathrm{p}}$ considering three different BWRO configurations and using samples 20 and 5 (Table 1 ) as feedwater.

\begin{tabular}{|c|c|c|c|c|c|c|c|c|}
\hline \multirow[b]{2}{*}{ Configuration } & \multicolumn{4}{|c|}{ Sample 20} & \multicolumn{4}{|c|}{ Sample 5} \\
\hline & $P_{\text {in }}(\mathrm{kW})$ & $p_{\mathrm{f}}$ (bar) & $Q_{\mathrm{f}}\left(\mathrm{m}^{3} \mathrm{~d}^{-1}\right)$ & $R(\%)$ & $P_{\text {in }}(\mathrm{kW})$ & $p_{\mathrm{f}}(\mathrm{bar})$ & $Q_{\mathrm{f}}\left(\mathrm{m}^{3} \mathrm{~d}^{-1}\right)$ & $R(\%)$ \\
\hline \multirow{25}{*}{ 1:0 } & 1.37 & 7.0 & 172 & 53.32 & 1.13 & 7.0 & 142 & 43.13 \\
\hline & 1.46 & 7.5 & 172 & 58.04 & 1.21 & 7.5 & 142 & 47.51 \\
\hline & 1.65 & 8.0 & 182 & 59.26 & 1.38 & 8.0 & 152 & 49.05 \\
\hline & 1.85 & 8.5 & 192 & 60.36 & 1.56 & 8.5 & 162 & 50.41 \\
\hline & 2.06 & 9.0 & 202 & 61.34 & 1.66 & 9.0 & 162 & 54.10 \\
\hline & 2.29 & 9.5 & 212 & 62.22 & 1.86 & 9.5 & 172 & 55.12 \\
\hline & 2.63 & 10.0 & 232 & 60.22 & 2.07 & 10.0 & 182 & 56.05 \\
\hline & 2.89 & 10.5 & 242 & 61.02 & 2.17 & 10.5 & 182 & 59.19 \\
\hline & 3.15 & 11.0 & 252 & 61.76 & 2.40 & 11.0 & 192 & 59.88 \\
\hline & 3.42 & 11.5 & 262 & 62.43 & 2.64 & 11.5 & 202 & 60.51 \\
\hline & 3.84 & 12.0 & 282 & 60.61 & 2.75 & 12.0 & 202 & 63.24 \\
\hline & 3.98 & 12.0 & 292 & 58.27 & 3.01 & 12.5 & 212 & 63.70 \\
\hline & & & & & 3.28 & 13.0 & 222 & 64.13 \\
\hline & & & & & 3.40 & 13.5 & 222 & 66.50 \\
\hline & & & & & 3.69 & 14.0 & 232 & 66.81 \\
\hline & & & & & 3.85 & 14.0 & 242 & 64.87 \\
\hline & & & & & 4.01 & 14.0 & 252 & 62.93 \\
\hline & & & & & 4.16 & 14.0 & 262 & 61.01 \\
\hline & & & & & 4.32 & 14.0 & 272 & 59.11 \\
\hline & & & & & 4.48 & 14.0 & 282 & 57.24 \\
\hline & & & & & 4.64 & 14.0 & 292 & 55.42 \\
\hline & & & & & 4.80 & 14.0 & 302 & 53.64 \\
\hline & & & & & 4.96 & 14.0 & 312 & 51.90 \\
\hline & & & & & 5.12 & 14.0 & 322 & 50.21 \\
\hline & & & & & 5.28 & 14.0 & 332 & 48.57 \\
\hline \multirow{25}{*}{$2: 1$} & 2.73 & 7.0 & 344 & 69.92 & 2.26 & 7.0 & 284 & 52.28 \\
\hline & 2.93 & 7.5 & 344 & 75.69 & 2.42 & 7.5 & 284 & 57.63 \\
\hline & 3.31 & 8.0 & 364 & 77.24 & 2.76 & 8.0 & 304 & 59.60 \\
\hline & 3.71 & 8.5 & 384 & 78.61 & 3.13 & 8.5 & 324 & 61.36 \\
\hline & 4.13 & 9.0 & 404 & 79.83 & 3.31 & 9.0 & 324 & 65.45 \\
\hline & 4.57 & 9.5 & 424 & 80.91 & 3.71 & 9.5 & 344 & 66.78 \\
\hline & 5.27 & 10.0 & 464 & 78.96 & 4.13 & 10.0 & 364 & 67.98 \\
\hline & 5.77 & 10.5 & 484 & 79.97 & 4.34 & 10.5 & 364 & 71.13 \\
\hline & 6.29 & 11.0 & 504 & 80.89 & 4.80 & 11.0 & 384 & 72.06 \\
\hline & 6.84 & 11.5 & 524 & 81.72 & 5.28 & 11.5 & 404 & 72.90 \\
\hline & 7.68 & 12.0 & 564 & 79.76 & 5.50 & 12.0 & 404 & 75.36 \\
\hline & & & & & 6.02 & 12.5 & 424 & 76.02 \\
\hline & & & & & 6.55 & 13.0 & 444 & 76.63 \\
\hline & & & & & 6.81 & 13.5 & 444 & 78.57 \\
\hline & & & & & 7.38 & 14.0 & 464 & 79.06 \\
\hline & & & & & 7.69 & 14.0 & 484 & 77.72 \\
\hline & & & & & 8.01 & 14.0 & 504 & 76.21 \\
\hline & & & & & 8.33 & 14.0 & 524 & 74.55 \\
\hline & & & & & 8.65 & 14.0 & 544 & 72.74 \\
\hline & & & & & 8.97 & 14.0 & 564 & 70.79 \\
\hline & & & & & 9.28 & 14.0 & 584 & 68.72 \\
\hline & & & & & 9.60 & 14.0 & 604 & 66.55 \\
\hline & 4.34 & 7.0 & 546 & 71.22 & 3.39 & 7.0 & 426 & 55.68 \\
\hline & 4.91 & 7.5 & 576 & 73.38 & 3.63 & 7.5 & 426 & 60.78 \\
\hline & 5.50 & 8.0 & 606 & 75.29 & 4.14 & 8.0 & 456 & 62.79 \\
\hline
\end{tabular}


Table A1. Cont.

\begin{tabular}{|c|c|c|c|c|c|c|c|c|}
\hline \multirow[b]{2}{*}{ Configuration } & \multicolumn{4}{|c|}{ Sample 20} & \multicolumn{4}{|c|}{ Sample 5} \\
\hline & $P_{\text {in }}(\mathrm{kW})$ & $p_{\mathrm{f}}$ (bar) & $Q_{\mathrm{f}}\left(\mathrm{m}^{3} \mathrm{~d}^{-1}\right)$ & $R(\%)$ & $P_{\text {in }}(\mathrm{kW})$ & $p_{\mathrm{f}}$ (bar) & $Q_{\mathrm{f}}\left(\mathrm{m}^{3} \mathrm{~d}^{-1}\right)$ & $R(\%)$ \\
\hline \multirow{20}{*}{$3: 2$} & 6.14 & 8.5 & 636 & 76.98 & 4.69 & 8.5 & 486 & 64.58 \\
\hline & 7.11 & 9.0 & 696 & 75.28 & 4.97 & 9.0 & 486 & 68.32 \\
\hline & 7.83 & 9.5 & 726 & 76.79 & 5.57 & 9.5 & 516 & 69.67 \\
\hline & 8.58 & 10.0 & 756 & 78.14 & 6.20 & 10.0 & 546 & 70.88 \\
\hline & 9.37 & 10.5 & 786 & 79.36 & 6.87 & 10.5 & 576 & 71.99 \\
\hline & 10.19 & 8.5 & 816 & 80.47 & 7.19 & 11.0 & 576 & 74.60 \\
\hline & 11.05 & 11.5 & 846 & 81.48 & 7.91 & 11.5 & 606 & 75.45 \\
\hline & 11.94 & 12.0 & 876 & 82.39 & 8.67 & 12.0 & 636 & 76.24 \\
\hline & 12.34 & 12.0 & 906 & 79.77 & 9.45 & 12.5 & 666 & 76.97 \\
\hline & & & & & 10.27 & 13.0 & 696 & 77.63 \\
\hline & & & & & 11.13 & 13.5 & 726 & 78.25 \\
\hline & & & & & 11.54 & 14.0 & 726 & 79.97 \\
\hline & & & & & 12.02 & 14.0 & 756 & 78.82 \\
\hline & & & & & 12.49 & 14.0 & 786 & 77.53 \\
\hline & & & & & 12.97 & 14.0 & 816 & 76.09 \\
\hline & & & & & 13.45 & 14.0 & 846 & 74.50 \\
\hline & & & & & 13.92 & 14.0 & 876 & 72.77 \\
\hline & & & & & 14.40 & 14.0 & 906 & 70.90 \\
\hline & & & & & 14.88 & 14.0 & 936 & 68.92 \\
\hline & & & & & 15.36 & 14.0 & 966 & 66.82 \\
\hline
\end{tabular}

Table A2. $P_{\mathrm{in}}, p_{\mathrm{f}}, Q_{\mathrm{f}}$ and $R$ for maximizing $Q_{\mathrm{p}}$ considering three different $\mathrm{BWRO}$ configurations and using samples 22 and 3 (Table 1 ) as feedwater.

\begin{tabular}{|c|c|c|c|c|c|c|c|c|}
\hline \multirow[b]{2}{*}{ Configuration } & \multicolumn{4}{|c|}{ Sample 22} & \multicolumn{4}{|c|}{ Sample 3} \\
\hline & $P_{\text {in }}(\mathrm{kW})$ & $p_{\mathrm{f}}(\mathrm{bar})$ & $Q_{\mathrm{f}}\left(\mathrm{m}^{3} \mathrm{~d}^{-1}\right)$ & $R(\%)$ & $P_{\text {in }}(\mathrm{kW})$ & $p_{\mathrm{f}}(\mathrm{bar})$ & $Q_{\mathrm{f}}\left(\mathrm{m}^{3} \mathrm{~d}^{-1}\right)$ & $R(\%)$ \\
\hline \multirow{29}{*}{$1: 0$} & 1.13 & 7.0 & 142 & 43.34 & 0.89 & 7.0 & 112 & 35.66 \\
\hline & 1.21 & 7.5 & 142 & 47.74 & 1.04 & 7.5 & 122 & 37.82 \\
\hline & 1.38 & 8.0 & 152 & 49.28 & 1.20 & 8.0 & 132 & 39.72 \\
\hline & 1.56 & 8.5 & 162 & 50.66 & 1.27 & 8.5 & 132 & 43.60 \\
\hline & 1.66 & 9.0 & 162 & 54.35 & 1.45 & 9.0 & 142 & 45.05 \\
\hline & 1.86 & 9.5 & 172 & 55.39 & 1.53 & 9.5 & 142 & 48.49 \\
\hline & 2.07 & 10.0 & 182 & 56.32 & 1.73 & 10.0 & 152 & 49.60 \\
\hline & 2.17 & 10.5 & 182 & 59.47 & 1.93 & 10.5 & 162 & 50.60 \\
\hline & 2.40 & 11.0 & 192 & 60.17 & 2.02 & 11.0 & 162 & 53.51 \\
\hline & 2.64 & 11.5 & 202 & 60.81 & 2.25 & 11.5 & 172 & 54.28 \\
\hline & 2.75 & 12.0 & 202 & 63.52 & 2.34 & 12.0 & 172 & 56.90 \\
\hline & 3.01 & 12.5 & 212 & 64.00 & 2.58 & 12.5 & 182 & 57.49 \\
\hline & 3.28 & 13.0 & 222 & 64.43 & 2.69 & 13.0 & 182 & 59.85 \\
\hline & 3.40 & 13.5 & 222 & 66.80 & 2.94 & 13.5 & 192 & 60.30 \\
\hline & 3.56 & 13.5 & 232 & 64.83 & 3.05 & 14.0 & 192 & 62.43 \\
\hline & 3.71 & 13.5 & 242 & 62.85 & 3.33 & 14.5 & 202 & 62.77 \\
\hline & 3.86 & 13.5 & 252 & 60.89 & 3.61 & 15.0 & 212 & 63.08 \\
\hline & 4.02 & 13.5 & 262 & 58.95 & 3.73 & 15.5 & 212 & 64.96 \\
\hline & 4.17 & 13.5 & 272 & 57.05 & 3.91 & 15.5 & 222 & 63.36 \\
\hline & 4.32 & 13.5 & 282 & 55.19 & 4.08 & 15.5 & 232 & 61.73 \\
\hline & 4.48 & 13.5 & 292 & 53.38 & 4.26 & 15.5 & 242 & 60.10 \\
\hline & & & & & 4.43 & 15.5 & 252 & 58.47 \\
\hline & & & & & 4.61 & 15.5 & 262 & 56.84 \\
\hline & & & & & 4.79 & 15.5 & 272 & 55.24 \\
\hline & & & & & 4.96 & 15.5 & 282 & 53.65 \\
\hline & & & & & 5.14 & 15.5 & 292 & 52.09 \\
\hline & & & & & 5.31 & 15.5 & 302 & 50.56 \\
\hline & & & & & 5.49 & 15.5 & 312 & 49.06 \\
\hline & & & & & 5.67 & 15.5 & 322 & 47.59 \\
\hline
\end{tabular}


Table A2. Cont.

\begin{tabular}{|c|c|c|c|c|c|c|c|c|}
\hline \multirow[b]{2}{*}{ Configuration } & \multicolumn{4}{|c|}{ Sample 22} & \multicolumn{4}{|c|}{ Sample 3} \\
\hline & $P_{\text {in }}(\mathrm{kW})$ & $p_{\mathrm{f}}(\mathrm{bar})$ & $Q_{\mathrm{f}}\left(\mathrm{m}^{3} \mathrm{~d}^{-1}\right)$ & $R(\%)$ & $P_{\text {in }}(\mathrm{kW})$ & $p_{\mathrm{f}}$ (bar) & $Q_{\mathrm{f}}\left(\mathrm{m}^{3} \mathrm{~d}^{-1}\right)$ & $R(\%)$ \\
\hline \multirow{28}{*}{ 2:1 } & 2.26 & 7.0 & 284 & 52.45 & 1.78 & 7.0 & 224 & 41.58 \\
\hline & 2.42 & 7.5 & 284 & 57.79 & 2.08 & 7.5 & 244 & 44.18 \\
\hline & 2.76 & 8.0 & 304 & 59.78 & 2.40 & 8.0 & 264 & 46.51 \\
\hline & 3.13 & 8.5 & 324 & 61.55 & 2.55 & 8.5 & 264 & 51.04 \\
\hline & 3.31 & 9.0 & 324 & 65.62 & 2.90 & 9.0 & 284 & 52.85 \\
\hline & 3.71 & 9.5 & 344 & 66.96 & 3.06 & 9.5 & 284 & 56.66 \\
\hline & 4.13 & 10.0 & 364 & 68.17 & 3.45 & 10.0 & 304 & 58.08 \\
\hline & 4.34 & 10.5 & 364 & 71.29 & 3.86 & 10.5 & 324 & 59.37 \\
\hline & 4.80 & 11.0 & 384 & 72.23 & 4.05 & 11.0 & 324 & 62.40 \\
\hline & 5.54 & 11.5 & 424 & 71.19 & 4.49 & 11.5 & 344 & 63.43 \\
\hline & 6.05 & 12.0 & 444 & 72.03 & 4.69 & 12.0 & 344 & 66.01 \\
\hline & 6.87 & 12.5 & 484 & 70.87 & 5.17 & 12.5 & 364 & 66.84 \\
\hline & 7.44 & 13.0 & 504 & 71.64 & 5.37 & 13.0 & 364 & 69.03 \\
\hline & 8.03 & 13.5 & 524 & 72.35 & 5.89 & 13.5 & 384 & 69.70 \\
\hline & 8.34 & 13.5 & 544 & 70.38 & 6.10 & 14.0 & 384 & 71.58 \\
\hline & 8.65 & 13.5 & 564 & 68.28 & 6.65 & 14.5 & 404 & 72.14 \\
\hline & 8.95 & 13.5 & 584 & 66.08 & 7.22 & 15.0 & 424 & 72.66 \\
\hline & & & & & 7.46 & 15.5 & 424 & 74.22 \\
\hline & & & & & 7.81 & 15.5 & 444 & 73.14 \\
\hline & & & & & 8.17 & 15.5 & 464 & 71.95 \\
\hline & & & & & 8.52 & 15.5 & 484 & 70.66 \\
\hline & & & & & 8.87 & 15.5 & 504 & 69.26 \\
\hline & & & & & 9.22 & 15.5 & 524 & 67.76 \\
\hline & & & & & 9.57 & 15.5 & 544 & 66.15 \\
\hline & & & & & 9.93 & 15.5 & 564 & 64.46 \\
\hline & & & & & 10.28 & 15.5 & 584 & 62.68 \\
\hline & & & & & 10.63 & 15.5 & 604 & 60.82 \\
\hline & & & & & 10.98 & 15.5 & 624 & 58.91 \\
\hline \multirow{29}{*}{$3: 2$} & 3.39 & 7.0 & 426 & 55.82 & 2.67 & 7.0 & 336 & 43.99 \\
\hline & 3.63 & 7.5 & 426 & 60.91 & 3.12 & 7.5 & 366 & 46.70 \\
\hline & 4.14 & 8.0 & 456 & 62.92 & 3.60 & 8.0 & 396 & 49.12 \\
\hline & 4.69 & 8.5 & 486 & 64.73 & 3.82 & 8.5 & 396 & 53.51 \\
\hline & 4.97 & 9.0 & 486 & 68.44 & 4.35 & 9.0 & 426 & 55.38 \\
\hline & 5.57 & 9.5 & 516 & 69.79 & 4.60 & 9.5 & 426 & 58.99 \\
\hline & 6.20 & 10.0 & 546 & 71.02 & 5.18 & 10.0 & 456 & 60.46 \\
\hline & 6.87 & 10.5 & 576 & 72.13 & 5.79 & 10.5 & 486 & 61.79 \\
\hline & 7.94 & 11.0 & 636 & 71.39 & 6.07 & 11.0 & 486 & 64.60 \\
\hline & 8.70 & 11.5 & 666 & 72.39 & 6.74 & 11.5 & 516 & 65.67 \\
\hline & 9.89 & 12.0 & 726 & 71.51 & 7.03 & 12.0 & 516 & 68.02 \\
\hline & 10.73 & 12.5 & 756 & 72.41 & 7.75 & 12.5 & 546 & 68.89 \\
\hline & 12.04 & 13.0 & 816 & 71.44 & 8.06 & 13.0 & 546 & 70.87 \\
\hline & 12.97 & 13.5 & 846 & 72.26 & 8.83 & 13.5 & 576 & 71.58 \\
\hline & 17.26 & 14.0 & 1086 & 58.11 & 9.16 & 14.0 & 576 & 73.25 \\
\hline & & & & & 9.98 & 14.5 & 606 & 73.84 \\
\hline & & & & & 10.83 & 15.0 & 636 & 74.40 \\
\hline & & & & & 11.19 & 15.5 & 636 & 75.78 \\
\hline & & & & & 11.72 & 15.5 & 666 & 74.92 \\
\hline & & & & & 12.25 & 15.5 & 696 & 73.97 \\
\hline & & & & & 12.78 & 15.5 & 726 & 72.93 \\
\hline & & & & & 13.30 & 15.5 & 756 & 71.79 \\
\hline & & & & & 13.83 & 15.5 & 786 & 70.55 \\
\hline & & & & & 14.36 & 15.5 & 816 & 69.21 \\
\hline & & & & & 14.89 & 15.5 & 846 & 67.77 \\
\hline & & & & & 15.42 & 15.5 & 876 & 66.24 \\
\hline & & & & & 15.94 & 15.5 & 906 & 64.62 \\
\hline & & & & & 16.47 & 15.5 & 936 & 62.91 \\
\hline & & & & & 17.00 & 15.5 & 966 & 61.13 \\
\hline
\end{tabular}


Table A3. $P_{\text {in, }} p_{\mathrm{f}}, Q_{\mathrm{f}}$ and $R$ for maximizing $Q_{\mathrm{p}}$ considering three different BWRO configurations and using sample 11 (Table 1 ) as feedwater.

\begin{tabular}{|c|c|c|c|c|}
\hline Configuration & $P_{\text {in }}(\mathrm{kW})$ & $p_{\mathrm{f}}(\mathrm{bar})$ & $Q_{\mathrm{f}}\left(\mathrm{m}^{3} \mathrm{~d}^{-1}\right)$ & $R(\%)$ \\
\hline \multirow{36}{*}{$1: 0$} & 0.81 & 7.0 & 102 & 25.64 \\
\hline & 0.95 & 7.5 & 112 & 28.21 \\
\hline & 1.02 & 8.0 & 112 & 32.38 \\
\hline & 1.18 & 8.5 & 122 & 34.40 \\
\hline & 1.25 & 9.0 & 122 & 38.10 \\
\hline & 1.42 & 9.5 & 132 & 39.67 \\
\hline & 1.50 & 10.0 & 132 & 42.96 \\
\hline & 1.69 & 10.5 & 142 & 44.19 \\
\hline & 1.77 & 11.0 & 142 & 47.12 \\
\hline & 1.98 & 11.5 & 152 & 48.08 \\
\hline & 2.07 & 12.0 & 152 & 50.71 \\
\hline & 2.30 & 12.5 & 162 & 51.47 \\
\hline & 2.39 & 13.0 & 162 & 53.83 \\
\hline & 2.64 & 13.5 & 172 & 54.42 \\
\hline & 2.73 & 14.0 & 172 & 56.56 \\
\hline & 3.00 & 14.5 & 182 & 57.03 \\
\hline & 3.10 & 15.0 & 182 & 58.97 \\
\hline & 3.38 & 15.5 & 192 & 59.33 \\
\hline & 3.49 & 16.0 & 192 & 61.10 \\
\hline & 3.78 & 16.5 & 202 & 61.38 \\
\hline & 3.90 & 17.0 & 202 & 63.00 \\
\hline & 4.09 & 17.0 & 212 & 61.63 \\
\hline & 4.29 & 17.0 & 222 & 60.24 \\
\hline & 4.48 & 17.0 & 232 & 58.83 \\
\hline & 4.67 & 17.0 & 242 & 57.41 \\
\hline & 4.86 & 17.0 & 252 & 55.99 \\
\hline & 5.06 & 17.0 & 262 & 54.58 \\
\hline & 5.25 & 17.0 & 272 & 53.17 \\
\hline & 5.44 & 17.0 & 282 & 51.78 \\
\hline & 5.64 & 17.0 & 292 & 50.40 \\
\hline & 5.83 & 17.0 & 302 & 49.04 \\
\hline & 6.02 & 17.0 & 312 & 47.70 \\
\hline & 6.22 & 17.0 & 322 & 46.39 \\
\hline & 6.41 & 17.0 & 332 & 45.09 \\
\hline & 6.60 & 17.0 & 342 & 43.83 \\
\hline & 6.79 & 17.0 & 352 & 42.59 \\
\hline \multirow{20}{*}{$2: 1$} & 1.62 & 7.0 & 204 & 29.41 \\
\hline & 1.91 & 7.5 & 224 & 32.27 \\
\hline & 2.03 & 8.0 & 224 & 37.17 \\
\hline & 2.35 & 8.5 & 244 & 39.48 \\
\hline & 2.49 & 9.0 & 244 & 43.74 \\
\hline & 2.85 & 9.5 & 264 & 45.59 \\
\hline & 3.00 & 10.0 & 264 & 49.28 \\
\hline & 3.39 & 10.5 & 284 & 50.76 \\
\hline & 3.55 & 11.0 & 284 & 53.93 \\
\hline & 3.97 & 11.5 & 304 & 55.13 \\
\hline & 4.14 & 12.0 & 304 & 57.87 \\
\hline & 4.60 & 12.5 & 324 & 58.85 \\
\hline & 4.78 & 13.0 & 324 & 61.22 \\
\hline & 5.27 & 13.5 & 344 & 62.03 \\
\hline & 5.47 & 14.0 & 344 & 64.09 \\
\hline & 5.99 & 14.5 & 364 & 64.77 \\
\hline & 6.20 & 15.0 & 364 & 66.57 \\
\hline & 6.76 & 15.5 & 384 & 67.15 \\
\hline & 6.98 & 16.0 & 384 & 68.73 \\
\hline & 7.57 & 16.5 & 404 & 69.22 \\
\hline
\end{tabular}


Table A3. Cont.

\begin{tabular}{|c|c|c|c|c|}
\hline Configuration & $P_{\text {in }}(\mathrm{kW})$ & $p_{\mathrm{f}}(\mathrm{bar})$ & $Q_{\mathrm{f}}\left(\mathrm{m}^{3} \mathrm{~d}^{-1}\right)$ & $R(\%)$ \\
\hline & 7.80 & 17.0 & 404 & 70.61 \\
\hline & 8.18 & 17.0 & 424 & 69.67 \\
\hline & 8.57 & 17.0 & 444 & 68.65 \\
\hline & 8.96 & 17.0 & 464 & 67.54 \\
\hline & 9.34 & 17.0 & 484 & 66.36 \\
\hline & 9.73 & 17.0 & 504 & 65.10 \\
\hline & 10.11 & 17.0 & 524 & 63.77 \\
\hline & 10.50 & 17.0 & 544 & 62.36 \\
\hline & 10.89 & 17.0 & 564 & 60.87 \\
\hline & 11.27 & 17.0 & 584 & 59.32 \\
\hline & 11.66 & 17.0 & 604 & 57.71 \\
\hline & 12.04 & 17.0 & 624 & 56.05 \\
\hline & 12.43 & 17.0 & 644 & 54.34 \\
\hline \multirow{34}{*}{$3: 2$} & 2.43 & 7.0 & 306 & 31.26 \\
\hline & 2.86 & 7.5 & 336 & 34.26 \\
\hline & 3.05 & 8.0 & 336 & 39.22 \\
\hline & 3.53 & 8.5 & 366 & 41.63 \\
\hline & 3.74 & 9.0 & 366 & 45.86 \\
\hline & 4.27 & 9.5 & 396 & 47.77 \\
\hline & 4.50 & 10.0 & 396 & 51.36 \\
\hline & 5.08 & 10.5 & 426 & 52.90 \\
\hline & 5.32 & 11.0 & 426 & 55.93 \\
\hline & 5.95 & 11.5 & 456 & 57.18 \\
\hline & 6.21 & 12.0 & 456 & 59.76 \\
\hline & 6.90 & 12.5 & 486 & 60.80 \\
\hline & 7.17 & 13.0 & 486 & 63.02 \\
\hline & 7.91 & 13.5 & 516 & 63.87 \\
\hline & 8.20 & 14.0 & 516 & 65.78 \\
\hline & 8.99 & 14.5 & 546 & 66.50 \\
\hline & 9.30 & 15.0 & 546 & 68.16 \\
\hline & 10.14 & 15.5 & 576 & 68.77 \\
\hline & 10.46 & 16.0 & 576 & 70.22 \\
\hline & 11.35 & 16.5 & 606 & 70.75 \\
\hline & 11.70 & 17.0 & 606 & 72.03 \\
\hline & 12.28 & 17.0 & 636 & 71.24 \\
\hline & 12.86 & 17.0 & 666 & 70.39 \\
\hline & 13.43 & 17.0 & 696 & 69.47 \\
\hline & 14.01 & 17.0 & 726 & 68.49 \\
\hline & 14.59 & 17.0 & 756 & 67.43 \\
\hline & 15.17 & 17.0 & 786 & 66.31 \\
\hline & 15.75 & 17.0 & 816 & 65.11 \\
\hline & 16.33 & 17.0 & 846 & 63.83 \\
\hline & 16.91 & 17.0 & 876 & 62.48 \\
\hline & 17.49 & 17.0 & 906 & 61.07 \\
\hline & 18.07 & 17.0 & 936 & 59.59 \\
\hline & 18.65 & 17.0 & 966 & 58.05 \\
\hline & 19.22 & 17.0 & 996 & 56.44 \\
\hline
\end{tabular}

\section{References}

1. Qasim, M.; Badrelzaman, M.; Darwish, N.N.; Darwish, N.A.; Hilal, N. Reverse osmosis desalination: A state-of-the-art review. Desalination 2019, 459, 59-104. [CrossRef]

2. Karabelas, A.; Koutsou, C.; Kostoglou, M.; Sioutopoulos, D. Analysis of specific energy consumption in reverse osmosis desalination processes. Desalination 2018, 431, 15-21. [CrossRef]

3. Nassrullah, H.; Anis, S.F.; Hashaikeh, R.; Hilal, N. Energy for desalination: A state-of-the-art review. Desalination 2020, 491, 114569. [CrossRef] 
4. Kurihara, M.; Takeuchi, H. SWRO-PRO System in "Mega-ton Water System” for Energy Reduction and Low Environmental Impact. Water 2018, 10, 48. [CrossRef]

5. Voutchkov, N. Energy use for membrane seawater desalination-Current status and trends. Desalination 2018, 431, 2-14. [CrossRef]

6. Park, H.G.; Kwon, Y.N. Long-Term Stability of Low-Pressure Reverse Osmosis (RO) Membrane Operation-A Pilot Scale Study. Water 2018, 10, 93. [CrossRef]

7. Zhao, D.L.; Japip, S.; Zhang, Y.; Weber, M.; Maletzko, C.; Chung, T.S. Emerging thin-film nanocomposite (TFN) membranes for reverse osmosis: A review. Water Res. 2020, 173, 115557. [CrossRef]

8. Saleem, H.; Zaidi, S.J. Nanoparticles in reverse osmosis membranes for desalination: A state of the art review. Desalination 2020, 475, 114171. [CrossRef]

9. Ruiz-García, A.; Nuez, I. Performance Assessment of SWRO Spiral-Wound Membrane Modules with Different Feed Spacer Dimensions. Processes 2020, 8, 692. [CrossRef]

10. Okamoto, Y.; Lienhard, J.H. How RO membrane permeability and other performance factors affect process cost and energy use: A review. Desalination 2019, 470, 114064. [CrossRef]

11. Ruiz-García, A.; de la Nuez Pestana, I. Feed Spacer Geometries and Permeability Coefficients. Effect on the Performance in BWRO Spriral-Wound Membrane Modules. Water 2019, 11, 152. [CrossRef]

12. Anis, S.F.; Hashaikeh, R.; Hilal, N. Reverse osmosis pretreatment technologies and future trends: A comprehensive review. Desalination 2019, 452, 159-195. [CrossRef]

13. Li, Y.; Yang, S.; Zhang, K.; Bart Van der Bruggen. Thin film nanocomposite reverse osmosis membrane modified by two dimensional laminar MoS2 with improved desalination performance and fouling-resistant characteristics. Desalination 2019, 454, 48-58. [CrossRef]

14. Li, S.; Cai, Y.H.; Schäfer, A.I.; Richards, B.S. Renewable energy powered membrane technology: A review of the reliability of photovoltaic-powered membrane system components for brackish water desalination. Appl. Energy 2019, 253, 113524. [CrossRef]

15. Joseph, A.; Damodaran, V. Dynamic simulation of the reverse osmosis process for seawater using LabVIEW and an analysis of the process performance. Comput. Chem. Eng. 2019, 121, 294-305. [CrossRef]

16. Rivas-Perez, R.; Sotomayor-Moriano, J.; Pérez-Zuñiga, G.; Soto-Angles, M.E. Real-Time Implementation of an Expert Model Predictive Controller in a Pilot-Scale Reverse Osmosis Plant for Brackish and Seawater Desalination. Appl. Sci. 2019, 9, 2932. [CrossRef]

17. Alatiqi, I.; Ghabris, A.; Ebrahim, S. System identification and control of reverse osmosis desalination. Desalination 1989, 75, 119-140. [CrossRef]

18. Robertson, M.; Watters, J.; Desphande, P.; Assef, J.; Alatiqi, I. Model based control for reverse osmosis desalination processes. Desalination 1996, 104, 59-68. [CrossRef]

19. Assef, J.Z.; Watters, J.C.; Deshpande, P.B.; Alatiqi, I.M. Advanced control of a reverse osmosis desalination unit. J. Process Contr. 1997, 7, 283-289. [CrossRef]

20. Abbas, A. Model predictive control of a reverse osmosis desalination unit. Desalination 2006, 194, $268-280$. [CrossRef]

21. Gambier, A.; Wellenreuther, A.; Badreddin, E. Control system design of reverse osmosis plants by using advanced optimization techniques. Desalin. Water Treat. 2009, 10, 200-209. [CrossRef]

22. Bartman, A.R.; Christofides, P.D.; Cohen, Y. Nonlinear Model-Based Control of an Experimental Reverse-Osmosis Water Desalination System. Ind. Eng. Chem. Res. 2009, 48, 6126-6136. [CrossRef]

23. McFall, C.W.; Christofides, P.D.; Cohen, Y.; Davis, J.F. Fault-tolerant control of a reverse osmosis desalination process. IFAC Proc. Vol. 2007, 40, 161-166. [CrossRef]

24. Kim, G.; Park, J.; Kim, J.; Lee, H.; Heo, H. PID control of Reverse Osmosis desalination plant using Immune-Genetic Algorithm. In Proceedings of the 2009 ICCAS-SICE, Fukuoka, Japan, 18-21 August 2009; pp. 2977-2981.

25. Bartman, A.R.; McFall, C.W.; Christofides, P.D.; Cohen, Y. Model-predictive control of feed flow reversal in a reverse osmosis desalination process. J. Process Contr. 2009, 19, 433-442. [CrossRef]

26. Bartman, A.R.; Zhu, A.; Christofides, P.D.; Cohen, Y. Minimizing energy consumption in reverse osmosis membrane desalination using optimization-based control. J. Process Contr. 2010, 20, 1261-1269. [CrossRef]

27. Al-haj, M.A.; Ajbar, A.; Ali, E.; Alhumaizi, K. Robust model-based control of a tubular reverse-osmosis desalination unit. Desalination 2010, 255, 129-136. [CrossRef] 
28. Emad, A.; Ajbar, A.; Almutaz, I. Periodic control of a reverse osmosis desalination process. J. Process Contr. 2012, 22, 218-227. [CrossRef]

29. Gambier, A. Control of a Reverse Osmosis plant by using a robust PID design based on multi-objective optimization. In Proceedings of the 2011 50th IEEE Conference on Decision and Control and European Control Conference, Orlando, FL, USA, 12-15 December 2011; pp. 7045-7050.

30. AlDhaifallah, M.; Sassi, K.; Mujtaba, I. PID Control of Reverse Osmosis Based Desalination Process. In Computer Aided Chemical Engineering, Proceedings of the 22nd European Symposium on Computer Aided Process Engineering; Bogle, I.D.L., Fairweather, M., Eds.; Elsevier: Amsterdam, The Netherlands, 2012; Volume 30, pp. 812-816. [CrossRef]

31. Li, D.; Yang, N.; Niu, R.; Qiu, H.; Xi, Y. FPGA based QDMC control for reverse-osmosis water desalination system. Desalination 2012, 285, 83-90. [CrossRef]

32. Zhao, T.; Niu, R.; Su, M.; Anderson, T. Steady state and dynamic modeling of RO desalination modules and system using EES. In Proceedings of the 2011 IEEE International Conference on Robotics and Automation, Shanghai, China, 9-13 May 2011; pp. 1-4.

33. Sobana, S.; Panda, R. Modeling and control of reverse osmosis desalination process using centralized and decentralized techniques. Desalination 2014, 344, 243-251. [CrossRef]

34. Phuc, B.D.H.; You, S.S.; Lim, T.W.; Kim, H.S. Modified PID control with $\mathrm{H} \infty$ loop shaping synthesis for RO desalination plants. Desalin. Water Treat. 2016, 57, 25421-25434. [CrossRef]

35. Phuc, B.D.H.; You, S.S.; Lim, T.W.; Kim, H.S. Dynamical analysis and control synthesis of RO desalination process against water hammering. Desalination 2017, 402, 133-142. [CrossRef]

36. Feliu-Batlle, V.; Rivas-Perez, R.; Linares-Saez, A. Fractional Order Robust Control of a Reverse Osmosis Seawater Desalination Plant. IFAC-PapersOnLine 2017, 50, 14545-14550. [CrossRef]

37. Zebbar, M.; Messlem, Y.; Gouichiche, A.; Tadjine, M. Super-twisting sliding mode control and robust loop shaping design of RO desalination process powered by PV generator. Desalination 2019, 458, 122-135. [CrossRef]

38. Khiari, W.; Turki, M.; Belhadj, J. Power control strategy for PV/Wind reverse osmosis desalination without battery. Control Eng. Pract. 2019, 89, 169-179. [CrossRef]

39. Ruiz-García, A.; Ruiz-Saavedra, E. 80,000 h operational experience and performance analysis of a brackish water reverse osmosis desalination plant. Assessment of membrane replacement cost. Desalination 2015, 375, 81-88. [CrossRef]

40. Ruiz-García, A.; Nuez, I. Long-term intermittent operation of a full-scale BWRO desalination plant. Desalination 2020, 489, 114526. [CrossRef]

41. Hasnain, S.M.; Alajlan, S.A. Coupling of PV-powered RO brackish water desalination plant with solar stills. Desalination 1998, 116, 57-64. [CrossRef]

42. Gocht, W.; Sommerfeld, A.; Rautenbach, R.; Melin, T.; Eilers, L.; Neskakis, A.; Herold, D.; Horstmann, V.; Kabariti, M.; Muhaidat, A. Decentralized desalination of brackish water by a directly coupled reverseosmosis-photovoltaic-system-A pilot plant study in Jordan. Renew. Energy 1998, 14, 287-292. [CrossRef]

43. Schäfer, A.; Remy, C.; Richards, B. Performance of a small solar-powered hybrid membrane system for remote communities under varying feedwater salinities. Water Supply 2004, 4, 233-243. [CrossRef]

44. Richards, B.; Capão, D.; Schäfer, A. Renewable Energy Powered Membrane Technology. 2. The Effect of Energy Fluctuations on Performance of a Photovoltaic Hybrid Membrane System. Environ. Sci. Technol. 2008, 42, 4563-4569. [CrossRef]

45. Richards, B.S.; Masson, L.; Schäfer, A.I. Impact of Feedwater Salinity on Energy Requirements of a Small-Scale Membrane Filtration System. In Appropriate Technologies for Environmental Protection in the Developing World: Selected Papers from ERTEP 2007, July 17-19 2007, Ghana, Africa; Yanful, E.K., Ed.; Springer: Dordrecht, The Netherlands, 2009; pp. 123-137. [CrossRef]

46. Khayet, M.; Essalhi, M.; Armenta-Déu, C.; Cojocaru, C.; Hilal, N. Optimization of solar-powered reverse osmosis desalination pilot plant using response surface methodology. Desalination 2010, 261, $284-292$. [CrossRef]

47. Qiblawey, H.; Banat, F.; Al-Nasser, Q. Performance of reverse osmosis pilot plant powered by Photovoltaic in Jordan. Renew. Energy 2011, 36, 3452-3460. [CrossRef]

48. Cherif, H.; Belhadj, J. Large-scale time evaluation for energy estimation of stand-alone hybrid photovoltaic-wind system feeding a reverse osmosis desalination unit. Energy 2011, 36, 6058-6067. [CrossRef] 
49. Park, G.L.; Schäfer, A.I.; Richards, B.S. Renewable energy powered membrane technology: The effect of wind speed fluctuations on the performance of a wind-powered membrane system for brackish water desalination. J. Membr. Sci. 2011, 370, 34-44. [CrossRef]

50. Richards, B.S.; Park, G.L.; Pietzsch, T.; Schäfer, A.I. Renewable energy powered membrane technology: Brackish water desalination system operated using real wind fluctuations and energy buffering. J. Membr. Sci. 2014, 468, 224-232. [CrossRef]

51. Richards, B.S.; Park, G.L.; Pietzsch, T.; Schäfer, A.I. Renewable energy powered membrane technology: Safe operating window of a brackish water desalination system. J. Membr. Sci. 2014, 468, 400-409. [CrossRef]

52. Richards, B.S.; Capão, D.P.; Früh, W.G.; Schäfer, A.I. Renewable energy powered membrane technology: Impact of solar irradiance fluctuations on performance of a brackish water reverse osmosis system. Sep. Purif. Technol. 2015, 156, 379-390. [CrossRef]

53. Ruiz-García, A.; de la Nuez-Pestana, I. A computational tool for designing BWRO systems with spiral wound modules. Desalination 2018, 426, 69-77. [CrossRef]

54. Ruiz-García, A.; Carrascosa-Chisvert, M.D.; Mena, V.; Souto, R.M.; Santana, J.J.; Nuez, I. Groundwater Quality Assessment in a Volcanic Mountain Range (South of Gran Canaria Island, Spain). Water 2019, 11, 754. [CrossRef]

55. Ruiz-García, A.; Ruiz-Saavedra, E.; Báez, S.O.P. Evaluation of the first seven years operating data of a RO brackish water desalination plant in Las Palmas, Canary Islands, Spain. Desalin. Water Treat. 2015, 54, 3193-3199. [CrossRef]

56. Wijmans, J.; Baker, R. The solution-diffusion model: A review. J. Membr. Sci. 1995, 107, 1-21. [CrossRef]

57. Al-Obaidi, M.; Kara-Zaitri, C.; Mujtaba, I. Scope and limitations of the irreversible thermodynamics and the solution diffusion models for the separation of binary and multi-component systems in reverse osmosis process. Comput. Chem. Eng. 2017, 100, 48-79. [CrossRef]

58. Kucera, J. Reverse Osmosis: Industrial Processes and Applications; John Wiley \& Sons: Hoboken, NJ, USA, 2015.

59. Ruiz-García, A.; Feo-García, J. Estimation of maximum water recovery in RO desalination for different feedwater inorganic compositions. Desalin. Water Treat. 2017, 70, 34-45. [CrossRef]

60. Solutions, D.W. Filmtec Reverse Osmosis Membranes Technical Manual; Dupont Water Solutions: Edina, MN, USA, 2020. 